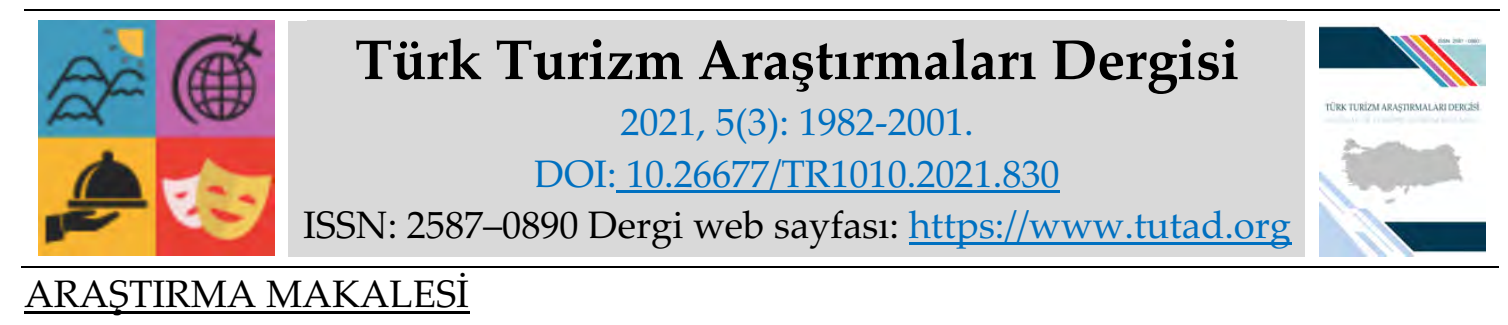

\title{
Covid 19 Pandemisi Sürecinde Turizm Eğitimi Alan Lise Öğrencilerinin Gelecek Beklentileri ve Turizm Sektörüne Yönelik Algıları Üzerine Bir Araştırma: Hatay Örneği
}

Öğr. Gör. Nurhayat İFLAZOĞU, Hatay Mustafa Kemal Üniversitesi, Turizm İşletmeciliği ve Otelcilik Yüksekokulu, Hatay, e-posta: nurhayat.iflazoglu@mku.edu.tr

ORCID: https://orcid.org/0000-0003-4736-789X

Arş. Gör. İpek Itır CAN, Anadolu Üniversitesi, Turizm Fakültesi, Eskişehir, e-posta: ipekic@anadolu.edu.tr

ORCID: https://orcid.org/0000-0003-4793-7151

Mehmet NUR, Hatay Nimet Fahri Öksüz Mesleki ve Teknik Anadolu Lisesi, Hatay, e-posta: memetnur@gmail.com

ORCID: https://orcid.org/0000-0002-9689-8622

Eymen CEVENT NISANİ, Hatay Nimet Fahri Öksüz Mesleki ve Teknik Anadolu Lisesi, Hatay, e-posta: eymencevent@gmail.com

ORCID: https://orcid.org/0000-0002-3643-0729

Öz

Bu araştırmada temel olarak COVID-19 Pandemisinin devam ettiği günlerde turizm eğitimi alan lise öğrencilerinin gelecek beklentileri ve turizm sektörüne yönelik algıları ile çeşitli sosyo-demografik değişkenler arasındaki farklılıklar belirlenmeye çalışılmıştır. Nicel yöntemin kullanıldığı bu çalışma, genel tarama modeline dayalı betimsel bir araştırmadır. Araştırmaya ilişkin veriler, 2021 yılının Mayıs ayında çevrimiçi anket aracılığıyla toplanmıştır. Çalışma kapsamında 453 anket toplanmış ve her bir anket doğruluğu, tutarlılığı ve tamlığı açısından bir değerlendirmeye tabi tutulmuştur. Bu değerlendirme sonucunda araştırmacılarda güven duygusu oluşturmayan sekiz anketin veri setinden çıkarılmasına karar verilmiş ve 445 anket üzerinden analizler gerçekleştirilmiştir. Bu kapsamda yüzde, frekans, aritmetik ortalama, t-testi ve Çok Değişkenli Varyans Analizi (MANOVA) analizi yapılmıştır. Araştırma sonuçlarına göre pandemiye rağmen kariyeri ile ilgili geleceğe umutla bakan ve turizm sektöründe çalışmaya devam etmek isteyen öğrencilerin oranı yüksektir. Fakat bu süreçte lise mezuniyeti sonrası iş bulma umut ve inançlarının olmadığ1 görülmektedir. Aldıkları eğitimin yeterli olduğunu bu şekilde sektörde başarılı olabileceğine inanan öğrenci sayısı yüksektir. Öte yandan, pandemi sebebiyle turizm sektörünün güvenilir bir seçim olmadığını düşünenlerin oranı $\% 44,7^{\prime}$ dir. Sonuç olarak uzun vadede öğrencilerin büyük çoğunluğunun kariyer gelişimlerinde geleceğe umutla baktıkları ve bu durumu yükseköğrenimlerine devam ederek perçinlemek istedikleri görülmektedir. Genel olarak ise öğrencilerin turizm sektörüne karşı olumsuz tutumlarının çalışma koşullarından kaynaklandığı tespit edilmiştir.

Anahtar Kelimeler: Turizm, Covid-19 Pandemisi, Gelecek Beklentisi, Turizm Sektör Algısı.

Makale Gönderme Tarihi: 13.05.2021

Makale Kabul Tarihi: 01.09.2021

\section{Önerilen Atıf:}

İflazoğlu, N., Can, İ. I., Nur, M. ve Cevent Nisani, E. (2021). Covid 19 Pandemisi Sürecinde Turizm Eğitimi Alan Lise Öğrencilerinin Gelecek Beklentileri ve Turizm Sektörüne Yönelik Algıları Üzerine Bir Araştırma: Hatay Örneği, Türk Turizm Araştırmaları Dergisi, 5(3): 1982-2001.

(c) 2021 Türk Turizm Araştırmaları Dergisi. 


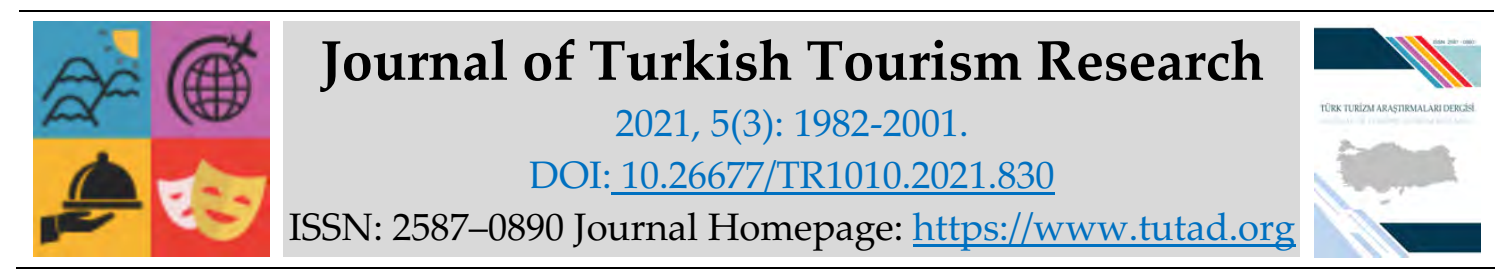

RESEARCH PAPER

\title{
A Research on Future Expectations and Perceptions Towards the Tourism Sector of the Adolescents' Receiving Tourism Education During the Covid 19 Pandemic: The Case of Hatay
}

Lecturer Nurhayat İFLAZOĞU, Hatay Mustafa Kemal University, School of Tourism and Hotel Management, Hatay, email: nurhayat.iflazoglu@mku.edu.tr

ORCID: https://orcid.org/0000-0003-4736-789X

Research Assistant İpek Itır CAN, Anadolu University, Faculty of Tourism, Eskişehir, e-mail: ipekic@anadolu.edu.tr ORCID: https://orcid.org/0000-0003-4793-7151

Mehmet NUR, Hatay Nimet Fahri Öksüz Vocational and Technical Anatolian High School, Hatay, e-mail: memetnur@gmail.com

ORCID: https://orcid.org/0000-0002-9689-8622

Eymen CEVENT NISANI, Hatay Nimet Fahri Öksüz Vocational and Technical Anatolian High School, Hatay, e-mail: eymencevent@gmail.com

ORCID: https://orcid.org/0000-0002-3643-0729

\begin{abstract}
The main purpose of this research is to determine the differences between the future expectations and perceptions of the tourism sector and various socio-demographic variables of adolescents' who received tourism education during the days of the COVID-19 Pandemic. This study, in which the quantitative method was used, is a descriptive research based on the general survey model. Data for the research were collected through an online survey in May 2021. Within the scope of the study, 453 questionnaires were collected and each questionnaire was evaluated in terms of accuracy, consistency and completeness. As a result of this evaluation, it was decided to remove eight questionnaires that did not create a sense of confidence in the researchers from the data set and analyzes were carried out on 445 questionnaires. In this context, percentage, frequency, arithmetic mean, t-test and Multivariate Analysis of Variance (MANOVA) analysis were performed. According to the results of the research, despite the pandemic, the rate of students who look forward to the future with hope and want to continue working in the tourism sector is high. However, in this process, it is seen that they do not have hope and belief in finding a job after high school graduation. On the other hand, the rate of those who think that the tourism sector is not a reliable choice due to the pandemic is $44.7 \%$. As a result, in the long run, it is seen that the majority of the students look to the future with hope in their career development and they want to reinforce this situation by continuing their higher education. In general, it was determined that the negative attitudes of the students towards the tourism sector were caused by the working conditions.
\end{abstract}

Keywords: Tourism, Covid-19 Pandemic, Future Expectation, Tourism Sector Perception.

Received: 13.05 .2021

Accepted: 01.09.2021

Suggested Citation:

İflazoğlu, N., Can, İ. I., Nur, M. and Cevent Nisani, E. (2021). A Research on Future Expectations and Perceptions Towards the Tourism Sector of the Adolescents' Receiving Tourism Education During the Covid 19 Pandemic: The Case of Hatay, Journal of Turkish Tourism Research, 5(3): 1982-2001.

(c) 2021 Türk Turizm Araştırmaları Dergisi. 


\section{Gíriş}

Turizm, istihdama doğrudan ve dolaylı olarak katkıda bulunan emek yoğun (insan faktörünün önemli rol aldığı) bir sektördür. Sektör, gerek yüksek vasıflı gerekse düşük vasıflı çalışanlar için potansiyel işler sağlayan, önde gelen bir istihdam ve iş yaratma kaynağıdır. Turizm sektörü önemli bir döviz kaynağı olduğu kadar bölgesel kalkınmaya da katkı sağlamakta ve çok sayıda işletmeyi desteklemektedir. Normal koşullarda sektör, sadece turizm eğitimi almış çalışanlara değil mülteciler, kadınlar, öğrenciler ve yaşlı çalışanlar için de farklı bölgelerde (şehir, kırsal ve kıyı alanları) çeşitli istihdam fırsatları sağlamaya yardımcı olmaktadır (OECD, 2020a). Uluslararası Çalışma Örgütü'nün (ILO) sektör raporuna göre, 2019'da turizm sektörü, dünya çapında yaklaşık 330 milyon doğrudan ve dolaylı istihdam yaratmış ve emek yoğun konaklama, seyahat acenteciliği ve tur operatörlüğü, yiyecek-içecek sektörleri tek başına dünya çapinda yaklaşık 144 milyon istihdam sağlamıştır (ILO, 2020).

Turizm sektörü, konaklama tesisleri, seyahat acenteleri, yiyecek-içecek işletmeleri ve diğer turizm firmalarının verdikleri hizmetler ile ülke ekonomisine maddi gelir ve istihdam açısından önemli katkılar sağlamaktadır. Buna karşın, Lee ve Chen'e göre (2011), güçlü ekonomik etkilerine karşılık turizm kırılgan yapıya sahip bir sektördür. Bir turizm destinasyonunun makro ve mikro çevresinde gerçekleşen olumsuz olaylar genellikle daha az ziyaretçi sayısı ile sonuçlanmaktadır. Özellikle insan sağlığı ya da güvenliği (savaş, salgın hastalık, doğal afetler, terörizm, siyasal, politik ve ekonomik istikrarsızlıklar vb.) ile ilgili hafif bir risk bile, turistik bir bölgenin tercih edilmemesi için yeterlidir. 2020 yılında tüm dünyayı etkisi altına alan COVID-19 salgını, turizm işletmelerini ve dolayısıyla çalışanlarının geçim kaynaklarını ciddi ölçüde etkilemiş, yüz milyonlarca insanın işsiz kalmasına neden olmuştur (Alaeddinoğlu ve Rol, 2020). Bu nedenle turizm, pandemiye karşı en savunmasız sektörlerden biri olarak tanımlanmıştır (ILO, 2020).

COVID-19 salgını, her şeyden önce insanların yaşamlarını her yönden (maddi, manevi) etkileyen uluslararası sorun haline gelmiş ve küresel bir ekonomik krizi tetiklemiştir. Özellikle turizmin ekonominin önemli bir parçası olduğu ülkelerde, şehirlerde ve bölgelerde salgının binlerce insan, yer ve işletme için yıkıcı etkileri olmuştur (OECD, 2020b). Dünya Turizm Örgütü'nün en son verilerine göre uluslararası turizm 2020'de rekor düzeyde en kötü yılını yaşamıştır (UNTWO, 2021a). 8 Mart 2020 yılı itibariyle uluslararası havacılığın durma noktasına gelmesi, turizm destinasyonlarının ve ilgi çekici yerlerin kapatılması, büyük festivallerin ve etkinliklerin iptal edilmesi veya ertelenmesi ve birçok ülkede halka açık etkinliklerin (iç ve dış mekân) kısıtlanması, COVID-19'un turizm üzerindeki yıkıcı etkisi hızlı bir toparlanma olasılığını yok etmiştir. Virüsün yayılması önümüzdeki aylarda kontrol altına alınsa bile, küresel turizmin 2020 yılı ve sonrasında ağır darbe alacağı ve toparlanma sürecinin 2024 yılını bulacağı öngörülmektedir (UNWTO, 2020b; Goodger ve Ferran, 2020). Turizm sektörünün yanı sıra, Dünya Bankası'nın raporuna göre COVID-19 salgınından önce de ciddi bir eğitim krizi yaşanmaktayken COVID-19 salgınıla beraber eğitim sorunları daha da kötüleşmiştir. Salgın dünya çapında eğitimin ilerlemesini tehdit etmektedir (World Bank, 2020). COVID-19 salgınından kaynaklı küresel kriz, dünyadaki hükümetler ve endüstriler üzerinde ani ve benzeri görülmemiş baskılar oluştururken neredeyse tüm sektörleri etkilemeye devam etmektedir. Birçok ülkede devam eden yasaklamalar, hem işyerlerinde hem de sınıfta öğrenmeyi kesintiye uğratmış, mesleki eğitimlerini ve becerileri değerlendirmek ve sonuç olarak yeterlilikleri vermek için kullanılan sistemler de dâhil olmak üzere işyeri tabanlı öğrenim için özellikle yıkıcı olmuştur. Krizle beraber birçok ülke, örgün öğrenmenin yerine, dijital platformlar oluşturmuş veya uyarlamıştır. Ancak, mesleki eğitimini de içeren iş temelli öğrenme programlarının uzaktan sağlanması ve değerlendirilmesi genellikle çok daha zordur. Yasaklar, sosyal mesafeler ve seyahat kısıtlamaları bağlamında mevcut mesleki teknik eğitimi öğrencileri için temel zorluk, sınıflarda, okul atölyelerinde veya işletmelerde eğitim almaları gerekliliğidir. Bazı mesleki alanlarda, teori çevrimiçi olarak öğretilebilir ve 
öğrenilebilir, ancak araçlara, malzemelere, ekipman ve makinelere erişim eksikliği nedeniyle pratik yönler etkili bir şekilde yapılamamaktadır. Bu durum mesleki ve teknik eğitimde önemli aksamalara neden olmaktadır. Ekonomik durgunluğun tüm dünyaya yayılacağının tahmin edilmesi ve bazı ülkelerde hali hazırda başlamış olması, talebin en düşük seviyelere ulaştığı otelcilik, turizm, yeme-içme, havacılık ve eğlence hizmetleri gibi sektörlerde belirli zorluklara neden olmaktadır. Dünyada örgün mesleki teknik eğitiminin etkin bir şekilde sağlanıp sağlanamayacağı ve öğrencilerin iş yeri tabanlı öğrenmeye erişimlerindeki belirsizlik devam etmektedir (OECD, 2020b).

Alanyazın incelendiğinde, yükseköğretim öğrencilerinin turizm sektörüne yönelik alg1 ve tutumlarının araştırıldığı çalışmalara (Kusluvan ve Kusluvan, 2000; Jenkins, 2001; Duman, Tepeci ve Unur 2006; Olcay ve Çelik, 2010; Çatı ve Bilgin, 2013; Unur, ve Köşker, 2015; Çavuş ve Kaya, 2015; Türker, Uçar, ve Ateş, 2016; Köşker ve Unur, 2017; Davras ve Alili, 2019; Kocaman ve Koybu Rol, 2020; Akpulat, 2020) rastlanmıştır. Turizm alanında eğitim gören lise öğrencilerinin mesleki algılarına yönelik erişilen sınırlı sayıda çalışmalar ise aşağıdaki gibidir:

Ross (1994), Avustralyalı lise öğrencilerinin turizm sektörüne yönelik kariyer hedeflerini incelediği çalışmasında, öğrencilerin turizm sektöründe özellikle üst kademe pozisyonlarda çalışmaya istekli olduklarını bulgulamıştır. Airey ve Frontistis'in (1997), Yunanistan ve Birleşik Krallık'taki lise öğrencilerinin turizm sektörü hakkındaki tutumları ve kariyer planları ile ilgili gerçekleştirdikleri karşılaştırmalı çalışmalarının sonuçlarına göre Birleşik Krallık öğrencileri Yunanlı öğrencilere göre turizme karşı daha az olumlu bir tutuma sahiptir. Cothran ve Combrink (1999), Amerika'nın Arizona eyaletinde bulunan lise öğrencilerinin konaklama sektöründe kariyer yapmaya yönelik tutumlarını inceledikleri çalışmalarında öğrencilerin sektör hakkındaki tutumlarının olumlu olduğu ve turizm sektöründeki kariyerlerine yönelik eğitim ve öğretim programlarına daha fazla ilgi duyduklarını tespit etmişlerdir. Duman, Tepeci ve Unur (2006), yükseköğretim (lisans ve önlisans) ve ortaöğretim (lise) düzeyinde turizm eğitimi almakta olan öğrencilerin, sektörün çalışma koşullarını algılamaları ve çalışma isteklerinin (kariyer beklentilerinin) karşılaştırmalı bir değerlendirmesini yaptıkları çalışmalarında, öğrencilerin eğitim seviyeleri ve cinsiyetlerine göre sektörün çalışma koşullarını algılamaları ve sektörde çalışma isteklerine ilişkin düşüncelerinde farklılıklar bulmuşlardır. Öğrencilerin sektörde çalışma isteklerini etkileyen en önemli unsurlar olarak kişi-endüstri uyumu-terfi imkânları ve sektörde çalışmanın sağlayacağı sosyal statü olarak tespit edilmiştir. Dagsland, Mykletun ve Einarsen (2017), çalışmalarında Norveçli lise öğrencilerinin turizm sektöründe kariyer yapma niyetlerini 2002 ve 2011 yılında topladıkları verilerle karşılaştırmalı olarak ele almıştır. Elde edilen verilere göre, her iki grup turizm sektöründe kariyer yapmaya olumlu bakmakta ayrıca sektörü ilginç ve heyecan verici olarak algılamakta, sektörün kişisel gelişim ve kariyer gelişimi için statü ve olanaklar sağladığını düşünmektedirler.

Yukarıda incelenen çalışmalarda COVID-19 pandemisi döneminde öğrencilerin gelecek beklentilerinin ve turizm sektörüne ilişkin algılarının temel alındığı bir çalışmaya rastlanmamıştır. Dolayısıyla bu çalışmada hem turizm sektöründe hem de eğitim alanında pandemi kaynaklı belirsizliklerin bu süreçte turizm eğitimi alan lise öğrencilerinin gelecek beklentileri ve turizm sektörüne yönelik algılarına nasıl etki ettiğine odaklanılmaktadır. Literatürde, öğrencilerin gelecek ile ilgili beklentilerinin ve turizm sektörüne yönelik algılarının yalnızca iş bulma ile ilgili kaygılarla sınırlı olmadığı görülmektedir. Halıcı ve Delil'e göre (2003: 22), bir meslekle ilgili özelliklerin ilgili programlarda okuyan öğrenciler tarafından nasıl algılandığının belirlenmesi, o mesleğin toplumda nasıl algılandığını ve olması gerektiği şekilde anlaşılıp anlaşılmadığını göstermektedir. Bu açıklamalar ışığında turizm eğitimi alan geleceğin turizmcilerinin, sektör algılarının pek çok sosyo-demografik faktörden etkilenebileceğini ve algılarının belirlenmesi gerektiğini söylemek mümkündür. $\mathrm{Bu}$ doğrultuda, çalışmada 
öğrencilerin gelecek beklentilerini ve turizm sektörüne yönelik algılarını incelemeye yönelten durum, COVID-19 pandemisinin hem turizm eğitimine hem de turizm sektörüne verdiği yıkıcı etkidir. Dolayısıyla turizm sektörü ile ilgili bu ve benzeri olumsuz algılar öğrencilerin meslek tercihlerini doğrudan etkilemekte ve sektörün ihtiyacı olan eğitimli insan gücünün kaybedilmemesi açısından öğrencilerin sektörle ilgili algı ve beklentilerinin mercek altına alınması büyük önem taşımaktadır. Pandemi döneminde turizm eğitimi alan lise öğrencilerinin gelecek beklentileri ve turizm sektörüne yönelik algılarının incelenmesi amacıyla yapılan bu araştırma, Hatay il sınırları içerisinde bulunan Nimet Fahri Öksüz Mesleki ve Teknik Anadolu Lisesi ve Uluçınar Mesleki ve Teknik Anadolu Lisesi (Önceki adları: Otelcilik ve Turizm Meslek Lisesi) Konaklama ve Seyahat Hizmetleri ile Yiyecek İçecek Hizmetleri alanlarında öğrenimlerine devam eden öğrencileri kapsamaktadır. Araştırma hem zaman kıstası hem de pandemi nedeniyle Hatay'da sadece turizm eğitimi veren meslek liseleri ve bölümleri ile sınırlandırılmıştır.

\section{KURAMSAL ÇERÇEVE}

\section{Mesleki ve Teknik Ortaöğretim}

Türkiye' de eğitim sistemi, örgün ve yaygın eğitim olmak üzere iki ana bölümden oluşmaktadır. Örgün eğitim belirli yaş grubundaki ve aynı seviyedeki bireylere, amaca göre hazırlanmış programlarla okul çatısı altında yapılan düzenli eğitimdir (Kalkınma Bakanlığı, 2014). Mesleki ve Teknik Ortaöğretim: İlköğretime dayalı en az dört yıllık zorunlu eğitimle öğrencilere genel kültür kazandırmanın yanı sıra, ilgi, istek ve yetenekleri doğrultusunda yükseköğretime, hem yükseköğretime hem mesleğe veya geleceğe ve iş alanlarına hazırlayan eğitim öğretim sürecidir. (Milli Eğitim Bakanlı̆̆ı, 2020a: xv). Öğrencilere iş ve mesleğe yönelik becerilerin kazandırılmasının eğitimsel bir konu olarak ele alınmasıyla ortaya çıkan meslekî eğitim, özellikle 18. yüzyıl ve sonrasında profesyonel bir eğitim alanı olarak kabul edilmeye başlanmıştır (Aytaç, 2006). Meslekî ve teknik eğitim, günümüzde eğitimin mesleklere yönelik insan ihtiyacının karşılanmasında, mezunlar ile istihdam alanları arasında denge kurulmasında önemli rol oynamaktadır (Bolat, 2016). Mesleki ve teknik ortaöğretim çeşitli programlar uygulayan mesleki ve teknik Anadolu liseleri, çok programlı liseler ve mesleki eğitim merkezlerinden oluşmaktadır ve 55 alanda ve bu alanlar altındaki 203 dalda öğretim programı uygulanmaktadır (Milli Eğitim Bakanlığı, 2020b).

\section{Mesleki ve Teknik Ortaöğretim: Turizm Liseleri}

Mesleki ve Teknik Anadolu liselerinde (önceki yıllarda Otelcilik ve Turizm Meslek Liseleri) turizm eğitimi; konaklama ve seyahat hizmetleri ile yiyecek içecek hizmetleri alanlarında ve bu alanların alt dallarında verilmektedir. Konaklama ve seyahat hizmetleri alanında öğrencilere konaklama tesisleri, konukların karşılanması, konuk ihtiyaçları ve kayıtları, konaklama tesisleri, kat hizmetleri, konuk hizmetleri, departmanın temizlik ve düzeni, tur programları, transfer işlemleri ve konukların karşılanması, yer ayırtma, konaklama işletmeleri ve rezervasyon ile ilgili yeterlilikleri kazandırmaya yönelik eğitim verilmektedir. Bu alanda eğitim gören öğrenciler, ilgi ve yetenekleri doğrultusunda Kat Hizmetleri, Operasyon, Ön Büro ve Rezervasyon dallarında eğitim almaktadır. Yiyecek ve içecek hizmetleri alanında ise öğrencilere otel, restoran, kafeterya, pastane, toplu beslenme kurumları, ulaştırma araçlarının (gemi, uçak, tren gibi) mutfakları ve servis hizmetleri vb. yerlerde hijyen ve sanitasyon kurallarına uygun yiyecek ve içeceklerin servise hazır hâle getirilip konuklara sunulması için gerekli yeterlilikler kazandırılmaktadır. Alan kapsamındaki eğitim Aş̧̧ılık, Hosteslik, Pasta ve Tatlı Yapımı ve Servis dallarında gerçekleştirilmektedir (Milli Eğitim Bakanlığı, 2018c). 


\section{ARAŞTIMA YÖNTEMI}

Bu araştırmada temel olarak COVID-19 Pandemisinin devam ettiği günlerde turizm eğitimi alan lise öğrencilerinin gelecek beklentileri ve turizm sektörüne yönelik algıları ile çeşitli sosyodemografik değişkenler arasındaki farklılıklar belirlenmeye çalışılmıştır. Nicel yöntemin kullanıldığı bu çalışma, genel tarama modeline dayalı betimsel bir araştırmadır. Araştırmaya ilişkin veriler, 2021 yılının Mayıs ayında çevrimiçi anket aracılığıyla toplanmıştır. Araştırmada kullanılan anket formundaki ifadeler Çavuş ve Kaya (2015), Davras ve Alili (2019), Kocaman ve Koybu Rol'un (2020) çalışmalarından yararlanılarak mevcut çalışmaya uyarlanmıştır. Veri toplama aracı, demografik sorular dışında; 3'ü çoktan seçmeli, $13^{\prime}$ ü evet/hayır ve $27^{\prime}$ si ise 5'li Likert ölçek olmak üzere 45 ifadeden oluşmaktadır. Taslak ölçek ifadelerine yönelik kapsam geçerliliğini sağlamak adına bu ifadelerin içerikleri hakkında öğretmen ve akademisyenlerin görüşleri alınarak bazı ifadelerin çıkartılmasına karar verilmiş, bazı ifadelerde de değişiklikler yapılmıştır. Ölçeğin dokuz maddesi ters kodlama gerektiren türde hazırlanmıştır.

Araştırmanın uygulama kısmı için öncelikle Hatay Mustafa Kemal Üniversitesi'nin Sosyal ve Beşerî Bilimler Bilimsel Araştırma ve Yayın Etiği Kurulu Başkanlığı'ndan 05.04.2021 tarih ve 2021/05 sayılı Etik Onay, Hatay Valiliği İl Milli Eğitim Müdürlügünden de araştırma izni onayı alınmıştır.

İlgili alan yazın incelendikten sonra, COVID-19 pandemisinin devam ettiği günlerde turizm eğitimi alan lise öğrencilerinin gelecek beklentileri ve turizm sektörüne yönelik algıları ile çeşitli sosyo-demografik değişkenler arasındaki farklılıkları belirleme amacıyla cevapları aranan sorular aşağıdaki gibi oluşturulmuştur:

AS1: Turizm eğitimi alan lise öğrencilerinin Covid-19 pandemisi sürecinde gelecek beklentileri nelerdir?

AS2:Turizm eğitimi alan lise öğrencilerinin Covid-19 pandemisi sürecinde turizm sektörüne yönelik algıları nasıldır?

AS3:Turizm eğitimi alan lise öğrencilerinin Covid-19 pandemisi sürecinde gelecek beklentileri ve turizm sektörüne yönelik algıları demografik özelliklerine göre farklılık göstermekte midir?

\section{Evren ve Örneklem}

Araştırmanın evreni, Mesleki ve Teknik liselerde öğrenim gören lise öğrencileri olup; örnekleme çerçevesini Hatay'da turizm alanında öğrenim gören lise öğrencileri oluşturmaktadır. Covid-19 pandemisinin devam ettiği günlerde turizm eğitimi alan lise öğrencilerinin gelecek beklentileri ve turizm sektörüne yönelik algıları iyi belirleyebilmek için uygulama alanı olan Hatay ilinde turizm eğitimi veren, Nimet Fahri Öksüz ve Uluçınar Mesleki ve Teknik Anadolu liseleri çalışma kapsamına alınmış; bu liseler amaçlı örnekleme yoluyla belirlenmiştir. Nimet Fahri Öksüz ve Uluçınar Mesleki ve Teknik Anadolu Liselerinde öğrenim gören ve örgün eğitimine devam eden 1129 öğrenci bulunmaktadır. Bu ölçekte bir evrene genellenebilecek örneklem sayısı 278'dir (Yazıcıŏlu ve Erdoğan, 2004). Araştırmada örneklem seçimi olarak ankete gönüllü cevap verebilecek herkesin örnekleme dahil edilmesi esasına dayanan (Coşkun vd., 2015), tesadüfi olmayan örnekleme yöntemlerinden kolayda örnekleme tercih edilmiştir. Çalışma kapsamında 453 anket toplanmış ve her bir anket doğruluğu, tutarlılığı ve tamlığı açısından bir değerlendirmeye tabi tutulmuştur. Bu değerlendirme sonucunda araştırmacılarda güven duygusu oluşturmayan sekiz anketin veri setinden çıkarılmasına karar verilmiş ve 445 anket üzerinden analizler gerçekleştirilmiştir. Elde edilen 445 anket, araştırma evrenini \%39,4 oranında (445/1129) temsil etmektedir. 


\section{Ölçeğin Güvenirlik ve Geçerlik Analizi}

COVID-19 Pandemisinin devam ettiği günlerde, turizm eğitimi alan lise öğrencilerinin gelecek beklentileri evet ve hayır şeklinde cevap verilmesi beklenen 13 ifade; turizm sektörüne yönelik algıları ise $5^{\prime}$ li likert tipi ile ölçülen (1=Kesinlikle katılmıyorum, 5=Kesinlikle katılıyorum) 27 ifade ile tespit edilmeye çalışılmıştır. Güvenirlik analizi sonucunda $+0,200$ 'ün altında olan iki madde (17. ve 27. Maddeler) aşamalı olarak ölçekten çıkarılmış ve geriye kalan 25 maddeli ölçeğin Cronbach's Alpha güvenirlik katsayısı 0,890 bulunmuştur. Bu katsayı doğrultusunda, ölçeğin "yüksek güvenirlikte" olduğunu söylemek mümkündür (Uzunsakal ve Yıldız, 2018). Başka bir deyişle, anket ifadelerine verilen cevapların tutarlı olduğu ve analizlerin sağlıklı bir şekilde yapılabileceği sonucuna ulaşılmıştır.

Ölçeğin yapı geçerliğini test etmek için, güvenirlik analizi sonucu iki maddesi ölçekten çıarılan ölçeğe açımlayıcı faktör analizi uygulanmıştır. Öncelikle verilerin faktör analizine uygunluğunun tespit edilebilmesi için Bartlett ve Kaiser-Meyer-Olkin (KMO) testleri gerçekleştirilmiştir. Değişkenler arasındaki korelasyonun yeterliliğini gösteren Bartlett testi sonucunda significant (sig.) değeri 0.000 olarak bulunmuştur. Bu değer 0.05 'ten küçük olduğu için değişkenler arasındaki korelasyonun yeterli olduğunu söylemek mümkündür (Bartlett, 1950). Örneklem sayısının analiz için yeterliliğini gösteren KMO değeri ise 0.942 olarak tespit edilmiştir. KMO'nun 0,90 ile 1,00 arasında bir değer alıyor olması "mükemmel" bir derecelendirmeye karşılık gelmektedir (Field, 2000). Ayrıca, faktör analizinin, tek boyutta toplam varyansın \%38,34'ünü; üç boyutta ise \%55,5'ini açıkladığı görülmüştür. Sosyal bilimlerde tek faktörlü yapılarda \%30'un üzerindeki değerler normal karşılanmaktadır (Çokluk, Şekercioğlu ve Büyüköztürk, 2012). Bu veriler doğrultusunda, ölçeğin yapı geçerliliğinin sağlandığı kabul edilmiştir.

\section{BULGULAR}

Araştırmaya katılan öğrencilerin \%57'si erkek, \%43'ü kadındır. Yaş ortalamaları 15,91'dir. \%55'i Nimet Fahri Öksüz Mesleki ve Teknik Anadolu Lisesi öğrencisi olup; \% 45'i Arsuz Uluçınar Mesleki ve Teknik Anadolu Lisesi öğrencisidir. \%35'i dokuzuncu, \%26's1 onuncu, \%23'ü on birinci sınıf ve 16 'sı on ikinci sınıftadır. Öğrencilerin \%51'i konaklama ve seyahat hizmetleri; $\% 49^{\prime}$ u ise yiyecek ve içecek hizmetleri alanındadır. Öğrencilerin \%66'sının babası ilkokul mezunu iken yalnızca \%2,5'inin babası üniversite mezunudur. \%75'inin babası pandemi öncesinde çalışmaktadır, buna karşın \%29,4'ünün babası pandemi döneminde artık çalışmamaktadır. Öğrencilerin \%61,7'sinin annesi ilkokul mezunu, \%1,1'inin annesi ise üniversite mezunudur. $\% 81,6$ 'sının annesi çalışmamaktadır. Aile gelir durumu incelendiğinde, öğrencilerin $\% 47,7^{\prime}$ sinin "gelir giderden az" seçeneğini işaretlediği, \%44'1'inin ise "gelir gidere denk" seçeneğini işaretlediği görülmektedir. Öğrencilerin \%67'si turizm lisesini kendi isteğiyle seçtiğini belirtmiş; bunu \%20,1 ile puanı doğrultusunda seçenler takip etmiştir. \%88,6'sı üniversite eğitimine devam etmek istemekte ve bunların \%70,5'i turizm alanında tercih yapacağını belirtmektedir. \%64,4'ü gastronomi ve mutfak sanatları, \%18,4'ü turizm işletmeciliği, \%15,5'i seyahat işletmeciliği ve turizm rehberliği ve $\% 1,7^{\prime}$ si rekreasyon yönetimi programlarına yönelmeyi düşünmektedir.

Turizm eğitimi alan lise öğrencilerinin Covid-19 pandemisi sürecinde gelecek beklentilerine ilişkin elde edilen bulgular Tablo 2'de verilmektedir. Bulgulara göre kariyeri ile ilgili geleceğe umut ve coşku ile bakan öğrencilerin oranı \%77,3'tür. Turizm sektöründe çalışmaya devam etmek isteyenlerin oranı \%76,2 iken turizm bölümünden mezun olanların iş bulmakta zorlandığını görenlerin oranı \%36,9'dur. Öğrencilerin liseden mezun olduktan sonraki planları incelendiğinde $\% 49^{\prime}$ unun mezuniyet sonrası ne yapacağına henüz karar vermediği, \%67,6'sının 
mezun olduktan sonra iş bulamama ihtimalinden korktuğu ve $\% 56,6$ sının mezuniyet sonrası hemen iş bulabileceğine inanmadığı görülmüştür. Öğrencilerin \%78'i aldığı eğitim sayesinde sektörde başarılı olabileceğini ve \%62'si aldığı eğitimin yeterli olduğunu düşünmektedir. Öğrencilerin \%71,5'i bir üst eğitime (üniversiteye) devam etmek istediklerini bildirirken, \%77,3'ü kısa sürede iyi noktalara geleceğine inandıklarını bildirmiştir. Son olarak, Covid-19 pandemisi sebebiyle turizm sektörünün güvenilir bir seçim olmadığını düşünenlerin oranı $\% 44,7$ olarak tespit edilmiştir.

Tablo 1. Katılımclların Demografik Bilgileri

\begin{tabular}{|l|l|}
\hline Cinsiyet & $\begin{array}{l}\text { Erkek: \%57 } \\
\text { Kadın: \%43 }\end{array}$ \\
\hline \multirow{3}{*}{ Okul } & $\begin{array}{l}\text { Nimet Fahri Öksüz M.T.A.L: \%55 } \\
\text { Arsuz Uluçınar M.T.A.L. Lisesi: \%45 }\end{array}$ \\
\hline Lise Alanı & $\begin{array}{l}\text { Dokuzuncu sınıf: \%35 } \\
\text { Onuncu sını: \%26 } \\
\text { On birinci sınıf: \%23 } \\
\text { On ikinci sınıf: \%16 }\end{array}$ \\
\hline \multirow{3}{*}{ Ailenin Gelir Düzeyi } & $\begin{array}{l}\text { Konaklama ve seyahat hizmetleri: \%51 } \\
\text { Yiyecek ve içecek hizmetleri: \%49 }\end{array}$ \\
\hline Turizm Lisesini Seçme Nedeni & $\begin{array}{l}\text { Gelir giderden az: \%47,7 } \\
\text { Gelir gidere denk: \%44,1 } \\
\text { Gelir giderden çok: \%11,2 }\end{array}$ \\
\hline Üniversite Alanı & $\begin{array}{l}\text { Kendim istedim: \%67 } \\
\text { Puanıma göre: \%20,1 } \\
\text { Ailemin karariydı: \%2 } \\
\text { Yakınlarımın tavsiyesiydi: \%4,9 } \\
\text { Başka seçeneğim yoktu: \%6 }\end{array}$ \\
\hline \multirow{2}{*}{ Üniversitede Tercih Edilmesi } & $\begin{array}{l}\text { Turizm alanında: \%70,5 } \\
\text { Farklı bir alanda: \%29,5 }\end{array}$ \\
Planlanan Turizm Programı & $\begin{array}{l}\text { Gastronomi ve mutfak sanatları: \%64,4 } \\
\text { Turizm işletmeciliği: \%18,4 } \\
\text { Seyahat işletmeciliği ve turizm rehberliği: \%15,5 } \\
\text { Rekreasyon yönetimi: \%1,7 }\end{array}$ \\
\hline
\end{tabular}

Turizm eğitimi alan lise öğrencilerinin Covid-19 pandemisi sürecinde turizm sektörüne yönelik tutumlarına ilişkin ifadelere verdikleri yanıtların sıklık değerleri, ortalamaları ve standart sapmaları Tablo 3'te gösterilmiştir. Tabloya göre ifadelere ilişkin en yüksek aritmetik ortalamaya sahip ifadelerin, sırasıyla, "turizmde farklı milletlerden insanlarla tanışmak mutlu edici bir tecrübedir" ( $\bar{x}=4,01)$, "turizm sektörünün toplum nezdinde kötü imajı vardır" $(\bar{x}=3,92)$ ve "kişiliğim turizm sektöründe çalışmaya uygundur" $(\bar{x}=3,86)$ olduğu görülmüştür. Diğer bir yandan en düşük aritmetik ortalamalar, sırasıyla, "turizmde iş güvenliği riski çok yüksektir" ( $\bar{x}$ $=2,84)$, "turizm sektöründe kariyer yapmak diğer sektörlere kiyasla daha kolaydır" $(\bar{x}=2,86)$ ve "turizmin mevsimsel olması kariyerim açısından sakınca yaratmaktadır" $(\bar{x}=2,89)$ ifadelerinde gözlemlenmiştir. 
Tablo 2. Katılımclların Covid-19 Pandemisi Sürecinde Gelecek Beklentilerine İlişkin Betimleyici Analizler

\begin{tabular}{|c|c|c|c|}
\hline & & $\mathbf{n}$ & $\%$ \\
\hline \multirow{3}{*}{ Kariyerim ile ilgili geleceğe umut ve coşku ile bakıyorum. } & Evet & 344 & 77,3 \\
\hline & Hayır & 101 & 22,7 \\
\hline & Toplam & 445 & 100 \\
\hline \multirow{3}{*}{ Turizm sektöründe çalışmaya devam etmek istiyorum. } & Evet & 339 & 76,2 \\
\hline & Hayır & 106 & 23,8 \\
\hline & Toplam & 445 & 100 \\
\hline \multirow{3}{*}{ Turizm sektöründe çalışmayı düşünmüyorum. } & Evet & 136 & 30,6 \\
\hline & Hayır & 309 & 69,4 \\
\hline & Toplam & 445 & 100 \\
\hline \multirow{3}{*}{ Kendi bölümümden mezun olanların iş bulmakta zorlandığını görüyorum. } & Evet & 164 & 36,9 \\
\hline & Hayır & 281 & 63,1 \\
\hline & Toplam & 445 & 100 \\
\hline \multirow{3}{*}{ Mezuniyet sonrası ne yapacağıma daha karar vermedim. } & Evet & 218 & 49,0 \\
\hline & Hayır & 227 & 51,0 \\
\hline & Toplam & 445 & 100 \\
\hline \multirow{3}{*}{ Mezun olduktan sonra iş bulamama ihtimali beni korkutuyor. } & Evet & 301 & 67,6 \\
\hline & Hayır & 144 & 32,4 \\
\hline & Toplam & 445 & 100 \\
\hline \multirow{3}{*}{ Mezun olduğumda hemen iş bulabileceğime inanıyorum. } & Evet & 193 & 43,4 \\
\hline & Hayır & 252 & 56,6 \\
\hline & Toplam & 445 & 100 \\
\hline \multirow{3}{*}{$\begin{array}{l}\text { Covid-19 pandemisi bana turizm sektörünün güvenilir bir seçim } \\
\text { olmadığını düşündürüyor. }\end{array}$} & Evet & 199 & 44,7 \\
\hline & Hayır & 246 & 55,3 \\
\hline & Toplam & 445 & 100 \\
\hline \multirow{3}{*}{ Mezuniyet sonrasında tam olarak ne yapacağımı bilmiyorum. } & Evet & 236 & 53,0 \\
\hline & Hayır & 209 & 47,0 \\
\hline & Toplam & 445 & 100 \\
\hline \multirow{3}{*}{$\begin{array}{l}\text { Aldığım eğitimle mezun olduktan sonra sektörde başarılı olabileceğimi } \\
\text { düşünüyorum. }\end{array}$} & Evet & 347 & 78,0 \\
\hline & Hayır & 98 & 22,0 \\
\hline & Toplam & 445 & 100 \\
\hline \multirow{3}{*}{ Aldığım eğitimin yeterli olduğunu düşünüyorum. } & Evet & 169 & 38,0 \\
\hline & Hayır & 276 & 62,0 \\
\hline & Toplam & 445 & 100 \\
\hline \multirow{3}{*}{ Bir üst eğitime (üniversite) devam etmek istiyorum. } & Evet & 318 & 71,5 \\
\hline & Hayır & 127 & 28,5 \\
\hline & Toplam & 445 & 100 \\
\hline \multirow{3}{*}{ Kısa sürede sektörde iyi noktalara geleceğimi düşünüyorum. } & Evet & 344 & 77,3 \\
\hline & Hayır & 101 & 22,7 \\
\hline & Toplam & 445 & 100 \\
\hline
\end{tabular}


Tablo 3. Katılımcıların Covid-19 Pandemisi Sürecinde Turizm Sektörüne Yönelik Tutumları

\begin{tabular}{|c|c|c|c|c|c|c|c|c|}
\hline İfadeler & & 1 & 2 & 3 & 4 & 5 & $\bar{x}$ & s.s. \\
\hline 1.Yurdışına çıkma fırsatı sunmaktadır. & $\begin{array}{c}\mathbf{f} \\
\%\end{array}$ & $\begin{array}{l}32 \\
\% 7,2\end{array}$ & $\begin{array}{l}40 \\
\% 9,0\end{array}$ & $\begin{array}{l}115 \\
\% 25,8\end{array}$ & $\begin{array}{l}162 \\
\% 36,4\end{array}$ & $\begin{array}{l}96 \\
\% 21,6\end{array}$ & 3,56 & 1,14 \\
\hline $\begin{array}{l}\text { 2.Turizmde farklı milletlerden insanlarla } \\
\text { tanışmak mutlu edici bir tecrübedir. }\end{array}$ & $\begin{array}{c}\mathrm{f} \\
\% \\
\end{array}$ & $\begin{array}{l}41 \\
\% 9,2 \\
\end{array}$ & $\begin{array}{l}11 \\
\% 2,5\end{array}$ & $\begin{array}{l}24 \\
\% 5,4 \\
\end{array}$ & $\begin{array}{l}196 \\
\% 44,0 \\
\end{array}$ & $\begin{array}{l}173 \\
\% 38,9 \\
\end{array}$ & 4,01 & 1,17 \\
\hline $\begin{array}{l}\text { 3.Turizm sektöründe çalışmak ilgi } \\
\text { çekicidir. }\end{array}$ & $\begin{array}{c}\mathrm{f} \\
\% \\
\end{array}$ & $\begin{array}{l}28 \\
\% 6,3 \\
\end{array}$ & $\begin{array}{l}37 \\
\% 8,3 \\
\end{array}$ & $\begin{array}{l}81 \\
\% 18,2 \\
\end{array}$ & $\begin{array}{l}194 \\
\% 43,6 \\
\end{array}$ & $\begin{array}{l}105 \\
\% 23,6 \\
\end{array}$ & 3,70 & 1,11 \\
\hline $\begin{array}{l}\text { 4.Turizm sektörü yeteneklerimi } \\
\text { kullanabilme imkânı sağlamaktadır. }\end{array}$ & $\begin{array}{r}\mathbf{f} \\
\% \\
\end{array}$ & $\begin{array}{ll}25 \\
\% 5,6\end{array}$ & $\begin{array}{ll}33 \\
\% 7,4\end{array}$ & $\begin{array}{ll}71 \\
\% 16,0 \\
\end{array}$ & $\begin{array}{ll}203 \\
\% 45,6 \\
\end{array}$ & $\begin{array}{ll}113 \\
\% 25,4 \\
\end{array}$ & 3,78 & 1,08 \\
\hline $\begin{array}{l}\text { 5.Turizm sektörü çalışanlara kariyer } \\
\text { imkânı sağlamaktadır. }\end{array}$ & $\begin{array}{c}\mathbf{f} \\
\%\end{array}$ & $\begin{array}{ll}34 \\
\% 7,6\end{array}$ & $\begin{array}{l}22 \\
\% 4,9\end{array}$ & $\begin{array}{ll}75 \\
\% 16,9 \\
\end{array}$ & $\begin{array}{l}213 \\
\% 47,9 \\
\end{array}$ & $\begin{array}{l}101 \\
\% 22,7 \\
\end{array}$ & 3,73 & 1,10 \\
\hline $\begin{array}{l}\text { 6.Topluma fayda sağlayabileceğim bir } \\
\text { meslektir. }\end{array}$ & $\begin{array}{c}\mathbf{f} \\
\%\end{array}$ & $\begin{array}{l}26 \\
\% 5,8\end{array}$ & $\begin{array}{l}20 \\
\% 4,5\end{array}$ & $\begin{array}{l}76 \\
\% 17,1\end{array}$ & $\begin{array}{l}225 \\
\% 50,6\end{array}$ & $\begin{array}{l}98 \\
\% 22\end{array}$ & 3,78 & 1,03 \\
\hline $\begin{array}{l}\text { 7.Turizmi bir kariyer yolu olarak } \\
\text { seçmemden dolayı çok mutluyum. }\end{array}$ & $\begin{array}{c}\mathrm{f} \\
\%\end{array}$ & $\begin{array}{l}36 \\
\% 8,1 \\
\end{array}$ & $\begin{array}{l}38 \\
\% 8,5 \\
\end{array}$ & $\begin{array}{l}92 \\
\% 20,7 \\
\end{array}$ & $\begin{array}{l}171 \\
\% 38,4 \\
\end{array}$ & $\begin{array}{l}108 \\
\% 24,3 \\
\end{array}$ & 3,62 & 1,17 \\
\hline $\begin{array}{l}\text { 8.Turizmde çalışanlar iyi paralar } \\
\text { kazanmaktadırlar. }\end{array}$ & $\begin{array}{c}\mathbf{f} \\
\%\end{array}$ & $\begin{array}{l}32 \\
\% 7,2\end{array}$ & $\begin{array}{l}23 \\
\% 5,2\end{array}$ & $\begin{array}{l}124 \\
\% 27,9\end{array}$ & $\begin{array}{l}184 \\
\% 41,3 \\
\end{array}$ & $\begin{array}{ll}82 \\
\% 18,4 \\
\end{array}$ & 3,59 & 1,07 \\
\hline $\begin{array}{l}\text { 9.Turizm eğitimi almam kariyer } \\
\text { gelişiminde doğru bir karardır. }\end{array}$ & $\begin{array}{c}\mathbf{f} \\
\%\end{array}$ & $\begin{array}{l}30 \\
\% 6,7\end{array}$ & $\begin{array}{l}41 \\
\% 9,2\end{array}$ & $\begin{array}{l}87 \\
\% 19,6 \\
\end{array}$ & $\begin{array}{l}193 \\
\% 43,4\end{array}$ & $\begin{array}{l}94 \\
\% 21,1\end{array}$ & 3,63 & 1,12 \\
\hline $\begin{array}{l}\text { 10.Yüksek nitelikli iş yapma donanımı } \\
\text { mevcuttur. }\end{array}$ & $\begin{array}{l}f \\
\% \\
\end{array}$ & $\begin{array}{l}25 \\
\% 5,6 \\
\end{array}$ & $\begin{array}{l}37 \\
\% 8,3 \\
\end{array}$ & $\begin{array}{l}138 \\
\% 31,0 \\
\end{array}$ & $\begin{array}{l}193 \\
\% 43,4 \\
\end{array}$ & $\begin{array}{l}52 \\
\% 11,7 \\
\end{array}$ & 3,47 & 0,99 \\
\hline $\begin{array}{l}\text { 11.Turizmde düzensiz ve uzun çalışma } \\
\text { saatleri vardır. }\end{array}$ & $\begin{array}{c}\mathbf{f} \\
\%\end{array}$ & $\begin{array}{l}32 \\
\% 7,2\end{array}$ & $\begin{array}{l}91 \\
\% 20,4 \\
\end{array}$ & $\begin{array}{l}138 \\
\% 31,0\end{array}$ & $\begin{array}{l}119 \\
\% 26,7\end{array}$ & $\begin{array}{l}65 \\
\% 14,6 \\
\end{array}$ & 3,21 & 1,14 \\
\hline 12.Turizmde cinsiyet ayrımcılığı yoktur. & $\begin{array}{c}\mathrm{f} \\
\% \\
\end{array}$ & $\begin{array}{l}46 \\
\% 10,3 \\
\end{array}$ & $\begin{array}{l}24 \\
\% 5,4 \\
\end{array}$ & $\begin{array}{l}59 \\
\% 13,3 \\
\end{array}$ & $\begin{array}{l}178 \\
\% 40,0 \\
\end{array}$ & $\begin{array}{l}138 \\
\% 31,0 \\
\end{array}$ & 3,76 & 1,24 \\
\hline $\begin{array}{l}\text { 13.Turizm sektöründe terfi olanakları } \\
\text { memnun edicidir. }\end{array}$ & $\begin{array}{c}\mathbf{f} \\
\%\end{array}$ & $\begin{array}{l}31 \\
\% 7,0\end{array}$ & $\begin{array}{ll}28 \\
\% 6,3\end{array}$ & $\begin{array}{l}123 \\
\% 27,6\end{array}$ & $\begin{array}{l}191 \\
\% 42,9\end{array}$ & $\begin{array}{l}72 \\
\% 16,2 \\
\end{array}$ & 3,55 & 1,06 \\
\hline 14. Turizm itibarlı bir meslektir. & $\begin{array}{c}\mathbf{f} \\
\%\end{array}$ & $\begin{array}{l}35 \\
\% 7,9\end{array}$ & $\begin{array}{l}13 \\
\% 2,9\end{array}$ & $\begin{array}{l}93 \\
\% 20,9\end{array}$ & $\begin{array}{l}220 \\
\% 39,4\end{array}$ & $\begin{array}{l}84 \\
\% 18,9\end{array}$ & 3,69 & 1,06 \\
\hline $\begin{array}{l}\text { 15.Turizm işletmelerinde iş yükü } \\
\text { oldukça fazladır. }\end{array}$ & $\begin{array}{l}\mathrm{f} \\
\% \\
\end{array}$ & $\begin{array}{l}57 \\
\% 12,8 \\
\end{array}$ & $\begin{array}{ll}171 \\
\% 38,4 \\
\end{array}$ & $\begin{array}{l}139 \\
\% 31,2 \\
\end{array}$ & $\begin{array}{l}45 \\
\% 10,1 \\
\end{array}$ & $\begin{array}{l}33 \\
\% 7,4 \\
\end{array}$ & 2,61 & 1,07 \\
\hline $\begin{array}{l}\text { 16.Turizm sektöründe kariyer yapmak } \\
\text { diğer sektörlere kıyasla daha kolaydır. }\end{array}$ & $\begin{array}{c}\mathbf{f} \\
\%\end{array}$ & $\begin{array}{l}48 \\
\% 10,8\end{array}$ & $\begin{array}{l}97 \\
\% 21,8 \\
\end{array}$ & $\begin{array}{l}190 \\
\% 42,7\end{array}$ & $\begin{array}{l}89 \\
\% 20,0 \\
\end{array}$ & $\begin{array}{l}21 \\
\% 4,7\end{array}$ & 2,86 & 1,01 \\
\hline $\begin{array}{l}\text { 17.Turizmin mevsimsel olması kariyerim } \\
\text { açısından sakınca yaratmaktadır. }\end{array}$ & $\begin{array}{c}\mathrm{f} \\
\% \\
\end{array}$ & $\begin{array}{l}59 \\
\% 13,3 \\
\end{array}$ & $\begin{array}{l}109 \\
\% 24,5 \\
\end{array}$ & $\begin{array}{l}140 \\
\% 31,5 \\
\end{array}$ & $\begin{array}{l}94 \\
\% 21,0 \\
\end{array}$ & $\begin{array}{l}43 \\
9,7 \\
\end{array}$ & 2,89 & 1,17 \\
\hline $\begin{array}{l}\text { 18.Turizmde iş güvenliği riski çok } \\
\text { yüksektir }\end{array}$ & $\begin{array}{c}\mathrm{f} \\
\% \\
\end{array}$ & $\begin{array}{l}45 \\
\% 10,1 \\
\end{array}$ & $\begin{array}{l}131 \\
\% 29,4 \\
\end{array}$ & $\begin{array}{l}156 \\
\% 35,1 \\
\end{array}$ & $\begin{array}{ll}77 \\
\% 17,3 \\
\end{array}$ & $\begin{array}{ll}36 \\
\% 8,1\end{array}$ & 2,84 & 1,08 \\
\hline $\begin{array}{l}\text { 19.Çalışma koşulları aile yaşamını } \\
\text { olumsuz etkilemektedir. }\end{array}$ & $\begin{array}{c}\mathbf{f} \\
\%\end{array}$ & $\begin{array}{l}12 \\
\% 2,7 \\
\end{array}$ & $\begin{array}{l}48 \\
\% 10,8 \\
\end{array}$ & $\begin{array}{l}134 \\
\% 30,1\end{array}$ & $\begin{array}{l}180 \\
\% 40,4 \\
\end{array}$ & $\begin{array}{l}71 \\
\% 16,0 \\
\end{array}$ & 3,56 & 0,97 \\
\hline $\begin{array}{l}\text { 20.Eğitimsiz insanlar önemli } \\
\text { pozisyonlarda görev alabilmektedir. }\end{array}$ & $\begin{array}{r}\mathbf{f} \\
\% \\
\end{array}$ & $\begin{array}{ll}33 \\
\% 7,4\end{array}$ & $\begin{array}{l}98 \\
\% 22,0 \\
\end{array}$ & $\begin{array}{ll}123 \\
\% 27,6 \\
\end{array}$ & $\begin{array}{ll}116 \\
\% 26,1 \\
\end{array}$ & \begin{tabular}{|l|}
75 \\
$\% 16,9$ \\
\end{tabular} & 3,23 & 1,18 \\
\hline $\begin{array}{l}\text { 21.Turizmde çalışmak gelecek } \\
\text { garantisini sağlamaz. }\end{array}$ & $\begin{array}{c}\mathbf{f} \\
\%\end{array}$ & $\begin{array}{l}19 \\
\% 4,3\end{array}$ & $\begin{array}{l}72 \\
\% 16,1 \\
\end{array}$ & $\begin{array}{l}138 \\
\% 31,0\end{array}$ & $\begin{array}{l}152 \\
\% 34,2\end{array}$ & $\begin{array}{l}64 \\
\% 14,4 \\
\end{array}$ & 3,38 & 1,05 \\
\hline $\begin{array}{l}\text { 22.İnsanlar tatildeyken onlara hizmet } \\
\text { etmek güzel değildir. }\end{array}$ & $\begin{array}{c}\mathrm{f} \\
\% \\
\end{array}$ & $\begin{array}{l}14 \\
\% 3,2 \\
\end{array}$ & $\begin{array}{l}48 \\
\% 10,8 \\
\end{array}$ & $\begin{array}{l}111 \\
\% 24,9 \\
\end{array}$ & $\begin{array}{l}170 \\
\% 38,2 \\
\end{array}$ & $\begin{array}{l}102 \\
\% 22,9 \\
\end{array}$ & 3,67 & 1,04 \\
\hline $\begin{array}{l}\text { 23.Çalışanların eğitim seviyesi genelde } \\
\text { düşüktür. }\end{array}$ & $\begin{array}{c}\mathrm{f} \\
\% \\
\end{array}$ & $\begin{array}{ll}14 \\
\% 3,1\end{array}$ & $\begin{array}{l}50 \\
\% 11,2 \\
\end{array}$ & $\begin{array}{l}116 \\
\% 26,1 \\
\end{array}$ & $\begin{array}{l}177 \\
\% 39,8 \\
\end{array}$ & $\begin{array}{l}88 \\
\% 19,8 \\
\end{array}$ & 3,62 & 1,02 \\
\hline $\begin{array}{l}\text { 24.Turizm sektörünün toplum nezdinde } \\
\text { kötü imajı vardır. }\end{array}$ & $\begin{array}{c}\mathbf{f} \\
\%\end{array}$ & $\begin{array}{ll}10 \\
\% 2,2\end{array}$ & $\begin{array}{l}26 \\
\% 5,8 \\
\end{array}$ & $\begin{array}{l}84 \\
\% 18,9 \\
\end{array}$ & $\begin{array}{l}193 \\
\% 43,4 \\
\end{array}$ & $\begin{array}{l}132 \\
\% 29,7\end{array}$ & 3,92 & 0,96 \\
\hline $\begin{array}{l}\text { 25.Turizm sektöründeki işlerde bilgi ve } \\
\text { becerilerimi kullanabilirim. }\end{array}$ & $\begin{array}{r}\mathrm{f} \\
\% \\
\end{array}$ & $\begin{array}{ll}31 \\
\% 7,0\end{array}$ & $\begin{array}{ll}23 \\
\% 5,1\end{array}$ & $\begin{array}{ll}56 \\
\% 12,6 \\
\end{array}$ & $\begin{array}{l}213 \\
\% 47,9 \\
\end{array}$ & $\begin{array}{ll}122 \\
\% 27,4 \\
\end{array}$ & 3,84 & 1,10 \\
\hline $\begin{array}{l}\text { 26.Kişiliğim turizm sektöründe } \\
\text { çalş̧maya uygundur. }\end{array}$ & $\begin{array}{l}\mathrm{f} \\
\% \\
\end{array}$ & $\begin{array}{l}35 \\
\% 7,9\end{array}$ & $\begin{array}{l}22 \\
\% 4,9\end{array}$ & $\begin{array}{l}50 \\
\% 11,2 \\
\end{array}$ & $\begin{array}{l}202 \\
\% 45,4 \\
\end{array}$ & $\begin{array}{l}136 \\
\% 30,6\end{array}$ & 3,86 & 1,14 \\
\hline $\begin{array}{l}\text { 27.İnsanlara hizmet etmek beni mutlu } \\
\text { eder. }\end{array}$ & $\begin{array}{l}\mathrm{f} \\
\%\end{array}$ & $\begin{array}{l}39 \\
\% 8,8\end{array}$ & $\begin{array}{l}34 \\
\% 7,6\end{array}$ & $\begin{array}{l}113 \\
\% 25,4\end{array}$ & $\begin{array}{l}154 \\
\% 34,6\end{array}$ & $\begin{array}{l}105 \\
\% 23,6\end{array}$ & 3,57 & 1,18 \\
\hline
\end{tabular}

Öğrencilerin turizm sektörüne yönelik tutumlarını ölçmek için tasarlanan ve iki maddesi güvenirlik analizi sonucu çıkarılan 25 maddeli ölçeğe uygulanan faktör analizi sonucu aşağıda 
yer alan Tablo 4'te görülmektedir. Bu ölçek için KMO değeri 0.942 olarak tespit edilmiş; Bartlett testi ise (Approx. Chi²: 5989.725; df: 300; Sig.: 0.000) anlamlı bulunmuştur. Böylelikle veri setinin faktör analizine uygunluğu teyit edilmiştir. Bunun yanı sıra, faktör analizinin, tek boyutta toplam varyansın \%38,34'ünü; üç boyutta ise \%55,5'ini açıkladı̆̆ı görülmüştür. Turizm sektörüne yönelik tutum ölçeğinde toplam üç alt boyut ortaya çıkmıştır. Birinci faktörü oluşturan 16 ifadenin anlamları dikkate alınarak faktör "olumlu tutum" olarak isimlendirilmiştir. "Olumsuz tutum" olarak isimlendirilen ikinci faktör altı ifadeden; "çalışma koşulları" olarak isimlendirilen üçüncü faktör ise üç ifadeden oluşmaktadır.

Faktör 1 (olumlu tutum) boyutunun ortalaması 3,65; standart sapması 0.83; çarpıklık değeri -1,36 ve basıklık değeri 2.08'dir. Faktör 2 (olumsuz tutum) boyutunun ortalaması 3,56; standart sapması 0.69; çarpıklık değeri -0.24 ve basıklık değeri 0.063 'tür. Faktör 3 (çalışma koşulları) boyutunun ise ortalaması 2,89; standart sapması 0.80; çarpıklık değeri 0.29 ve basıklık değeri 0.14 olarak tespit edilmiştir. Ortalamalar açısından değerlendirildiğinde, sıralamanın Faktör 1 (olumlu tutum), Faktör 2 (olumsuz tutum) ve Faktör 3 (çalışma koşulları) şeklinde olduğu ve tüm faktörlerin ortalamalarının "3: Ne katılıyorum ne katılmıyorum" tepki kategorisi civarında olduğu görülmüştür. Tabachnick, Fidell ve Ullman'a göre (2007) çarpıklık ve basıklık değerleri 1,5 ile $+1,5$ arasında olmalıdır; George ve Mallery'e göre ise (2010) bu değerler -2 ile +2 arasında olmalıdır. Bu doğrultuda, faktörlerin çarpıklık ve basıklık değerleri dikkate alındığında, verilerin normal dağıldığını söylemek mümkündür.

Tablo 4. Turizm Sektörüne Yönelik Tutum Ölçeğine İlişkin Açımlayıcı Faktör Analizi

\begin{tabular}{|c|c|c|c|}
\hline & \multicolumn{3}{|c|}{ Faktörler } \\
\hline İfadeler & Faktör 1 & Faktör 2 & Faktör 3 \\
\hline Turizm sektörü yeteneklerimi kullanabilme imkânı sağlamaktadır & .867 & & \\
\hline Turizmde farklı milletlerden insanlarla tanışmak mutlu edici bir tecrübedir & .864 & & \\
\hline Turizm sektörü çalışanlara kariyer imkânı sağlamaktadır & .858 & & \\
\hline Turizm sektöründe çalışmak ilgi çekicidir & .850 & & \\
\hline Turizm sektöründe kariyer yapmak diğer sektörlere kıyasla daha kolaydır & .832 & & \\
\hline Topluma fayda sağlayabileceğim bir meslektir & .794 & & \\
\hline Turizmi bir kariyer yolu olarak seçmemden dolayı çok mutluyum & .783 & & \\
\hline Turizm eğitimi almam kariyer gelişiminde doğru bir karardır & .782 & & \\
\hline Yurt dışına çıkma fırsatı sunmaktadır & .777 & & \\
\hline Kişiliğim turizm sektöründe çalışmaya uygundur & .776 & & \\
\hline Turizm sektöründeki işlerde bilgi ve becerilerimi kullanabilirim & .746 & & \\
\hline Turizmde çalışanlar iyi paralar kazanmaktadırlar & .710 & & \\
\hline Turizm itibarlı bir meslektir & .702 & & \\
\hline Yüksek nitelikli iş yapma donanımı mevcuttur & .612 & & \\
\hline Turizmde cinsiyet ayrımcllı̆̆ı yoktur & .595 & & \\
\hline Turizm sektöründe terfi olanakları memnun edicidir & .586 & & \\
\hline Turizm sektörünün toplum nezdinde kötü imajı vardır & & .783 & \\
\hline Çalışanların eğitim seviyesi genelde düşüktür & & .689 & \\
\hline Turizmde çalışmak gelecek garantisini sağlamaz & & .661 & \\
\hline Çalışma koşulları aile yaşamını olumsuz etkilemektedir & & .626 & \\
\hline İnsanlar tatildeyken onlara hizmet etmek güzel değildir & & .607 & \\
\hline Eğitimsiz insanlar önemli pozisyonlarda görev alabilmektedir & & .525 & \\
\hline Turizmde düzensiz ve uzun çalışma saatleri vardır & & & .714 \\
\hline Turizm işletmelerinde iş yükü oldukça fazladır & & & .701 \\
\hline Turizmde iş güvenliği riski çok yüksektir & & & .581 \\
\hline
\end{tabular}


Elde edilen faktörler ile cinsiyet, okul, alan, ebeveynlerin (anne ve babanın) çalışma durumu, üniversite okuma düşünceleri ve seçilmesi düşünülen üniversite programı arasındaki ilişkiler Bağımsız Örneklemler T-testi ile ortaya konmuş ve aşağıda yer alan Tablo 5 'te sunulmuştur. Gerçekleştirilen T-testlerinin sonucuna göre, cinsiyetin olumlu ve olumsuz tutum faktörleri üzerinde anlamlı bir farklılığa sahip olmadığı; buna karşın çalışma koşulları faktörü ile cinsiyet arasında anlamlı bir farklılık olduğu tespit edilmiştir $(\mathrm{p}=0.001<0.05)$. Buna göre, kadınlar erkeklere göre turizm sektörünün çalışma koşullarının daha ağır olduğunu düşünmektedir. Öğrencilerin okulları ve ebeveynlerinin çalışma durumları ile elde edilen faktörler arasında istatistiki olarak anlamlı bir farklılık bulunamamışır. Benzer bir şekilde, üniversite okuma düşünceleri de faktörler üzerinde anlamlı bir farklılık göstermemiştir. Öğrencilerin lise alanları (konaklama ve seyahat hizmetleri, yiyecek içecek hizmetleri) ile olumlu tutum ve çalışma koşulları faktörleri arasında anlamlı bir farklılık bulunamamış olsa da olumsuz tutum ile istatistiki bir anlamlılık tespit edilmiştir $(\mathrm{p}=0.007<0.05)$. Konaklama ve seyahat hizmetleri alanındaki lise öğrencileri, yiyecek ve içecek hizmetleri alanındakilere nazaran turizm sektörüne ilişkin daha olumsuz bir tutuma sahiptirler. Öğrencilerin üniversiteyi okumayı düşündüğü alan (turizm alanı veya farklı bir alan), öğrencilerin turizm sektörüne ilişkin olumlu ve olumsuz tutum faktörleri üzerinde anlamlı bir farklılığa sahiptir ( $\mathrm{p}=0.000<0.05)$.

Tablo 5. Faktörlere İlişkin T-Testi Sonuçları

\begin{tabular}{|c|c|c|}
\hline Değişkenler & \multicolumn{2}{|c|}{$\begin{array}{c}\text { T-testi Sonuçları } \\
\text { (Faktör 1: Olumlu Tutum; Faktör 2: Olumsuz Tutum; Faktör 3: Çalışma } \\
\text { Koşulları) }\end{array}$} \\
\hline Cinsiyet & $\begin{array}{l}\text { Faktör } 1 \text { ve Faktör } 2 \text { ile aralarında } \\
\text { istatistiki olarak anlamlı bir farklılık } \\
\text { bulunamamıştır. }\end{array}$ & $\begin{array}{l}\text { Faktör } 3 \text { ile arasında istatistiki olarak } \\
\text { anlamlı bir farklıllk bulunmuştur } \\
(\mathrm{p}=0.001<0.05) \text {. }\end{array}$ \\
\hline Okul & \multicolumn{2}{|c|}{$\begin{array}{l}\text { Faktör 1, Faktör } 2 \text { ve Faktör } 3 \text { ile aralarında istatistiki olarak anlamlı bir } \\
\text { farklılık bulunamamıştır. }\end{array}$} \\
\hline Anne ve Baba Çalışma Durumları & \multicolumn{2}{|c|}{$\begin{array}{l}\text { Faktör 1, Faktör } 2 \text { ve Faktör } 3 \text { ile aralarında istatistiki olarak anlamlı bir } \\
\text { farklılık bulunamamıştır. }\end{array}$} \\
\hline Üniversite Okuma Düşüncesi & \multicolumn{2}{|c|}{$\begin{array}{l}\text { Faktör 1, Faktör } 2 \text { ve Faktör } 3 \text { ile aralarında istatistiki olarak anlamlı bir } \\
\text { farklılık bulunamamiştır. }\end{array}$} \\
\hline Lise Alanı & $\begin{array}{l}\text { Faktör } 1 \text { ve Faktör } 3 \text { ile aralarında } \\
\text { istatistiki olarak anlamlı bir farklılık } \\
\text { bulunamamıştır. }\end{array}$ & $\begin{array}{l}\text { Faktör } 2 \text { ile arasında istatistiki olarak } \\
\text { anlamlı bir farklıllk bulunmuştur } \\
(\mathrm{p}=0.007<0.05) \text {. }\end{array}$ \\
\hline Üniversite Alanı & $\begin{array}{l}\text { Faktör } 3 \text { ile arasında istatistiki olarak } \\
\text { anlamlı bir farklılık bulunamamıştır }\end{array}$ & $\begin{array}{l}\text { Faktör } 1 \text { ve Faktör } 2 \text { ile aralarında } \\
\text { istatistiki olarak anlamlı bir farklılık } \\
\text { bulunmuştur }(\mathrm{p}=0.000<0.05) \text {. }\end{array}$ \\
\hline
\end{tabular}

Faktör analizi sonucunda belirlenen faktörlere ek olarak, öğrencilerin gelecek planlarını ve kaygı düzeylerini ölçen soruların ortalamaları alınarak "gelecek kaygıları" olarak adlandırılmış ve ilgili değişkenler arasında T-testi uygulanmıştır. Bulguların özetlenmiş hali Tablo 6'da verilmiştir. Gerçekleştirilen T-testlerinin sonucuna göre, cinsiyetin gelecek kaygıları üzerinde istatistiki olarak anlamlı bir farklılığa sahip olduğu tespit edilmiş $(\mathrm{p}=0.001<0.05)$ ve kadınların erkeklere nazaran geleceğe yönelik daha kaygılı olduğu görülmüştür. Buna karşın, okul, anne ve baba çalışma durumları ve lise alanı değişkenleri ile gelecek kaygıları arasında anlamlı bir farklılık bulunamamıştır. Öğrencilerin üniversite okuma düşünceleri $(\mathrm{p}=0.005<0.05)$ ve okumayı düşündükleri alan (turizm alanı veya farklı bir alan; $\mathrm{p}=0.000<0.05)$ değişkenleri ile gelecek kaygıları arasında anlamlı bir farklılık tespit edilmiştir. Buna göre, üniversite okuma düşüncesi 
olmayanların veya turizmden farklı bir alanda üniversite eğitimine devam etmeyi düşünenlerin gelecek kaygisı daha yüksektir.

Tablo 6. Gelecek Kaygılarına İlişkin T-Testi Sonuçları

\begin{tabular}{|l|l|}
\hline \multicolumn{1}{|c|}{ Değişkenler } & \multicolumn{1}{c|}{$\begin{array}{c}\text { T-testi Sonuçları } \\
\text { (Gelecek Kaygıları) }\end{array}$} \\
\hline Cinsiyet & $\begin{array}{l}\text { Gelecek kaygıları ile aralarında istatistiki olarak anlamlı bir farklılık } \\
\text { bulunmuştur }(p=0.001<0.05) .\end{array}$ \\
\hline Okul & $\begin{array}{l}\text { Gelecek kaygıları ile aralarında istatistiki olarak anlamlı bir farklılık } \\
\text { bulunamamışır. }\end{array}$ \\
\hline Anne ve Baba Çalışma Durumları & $\begin{array}{l}\text { Gelecek kaygıları ile aralarında istatistiki olarak anlamlı bir farklılık } \\
\text { bulunamamıştır. }\end{array}$ \\
\hline Üniversite Okuma Düşüncesi & $\begin{array}{l}\text { Gelecek kaygıları ile aralarında istatistiki olarak anlamlı bir farklılık } \\
\text { bulunmuştur }(p=0.005<0.05) .\end{array}$ \\
\hline Lise Alanı & $\begin{array}{l}\text { Gelecek kaygılları ile aralarında istatistiki olarak anlamlı bir farklılık } \\
\text { bulunamamiştır. }\end{array}$ \\
\hline Üniversite Alanı & $\begin{array}{l}\text { Gelecek kaygıları ile aralarında istatistiki olarak anlamlı bir farklılık } \\
\text { bulunmuștur }(p=0.000<0.05) .\end{array}$ \\
\hline
\end{tabular}

Elde edilen faktörler ile sınıf, ailenin gelir düzeyi, anne ve baba eğitim düzeyi, anne ve babanın pandemi sürecindeki çalışma durumu, liseyi seçme nedeni ve üniversitede tercih edilmesi planlanan turizm programı arasındaki ilişkiler Çok Değişkenli Varyans Analizi (MANOVA) ile ortaya konmuş ve Tablo 7'de sunulmuştur. Öğrencilerin sınıfları ile turizm sektörüne yönelik olumlu tutum ve çalışma koşulları faktörleri arasında anlamlı bir farklılık bulunmazken; olumsuz tutum ile arasında anlamlı bir farklılık bulunmaktadır (Pillai's Trace (sig.) $=0.000$; $\mathrm{p}=0.000<0.05$ ). 11. Sinıfların 9. Sinıflara göre; 12. Sinıfların ise 9. ve 10.Sınıflara göre turizm sektörüne yönelik olumsuz bir tutum sergileme oranı daha yüksektir. Aile gelir düzeyi, anne ve baba eğitim düzeyi, anne ve babanın pandemi sürecindeki çalışma durumu, liseyi seçme nedeni değişkenleri ile faktörler arasında istatistiki olarak anlamlı bir farklılık bulunmamıştır. Üniversitede tercih edilmesi planlanan turizm programı ile olumlu tutum faktörü arasında anlamlı bir farklılık tespit edilmiştir (Pillai's Trace (sig.) $=0.000 ; \mathrm{p}=0.009<0.05$ ). Buna göre, gastronomi ve mutfak sanatları veya seyahat işletmeciliği ve turizm rehberliği programlarını tercih etmeyi düşünen öğrencilerin, turizm işletmeciliği tercih etmeyi düşünenlere göre, turizm sektörüne yönelik olumlu tutum sergileme oranları daha yüksektir.

Tablo 7. Faktörlere İlişkin Çok Değişkenli Varyans Analizi (MANOVA) Sonuçları

\begin{tabular}{|c|c|c|}
\hline Değişkenler & \multicolumn{2}{|c|}{$\begin{array}{l}\text { MANOVA Sonuçları } \\
\text { (Faktör 1: Olumlu Tutum; Faktör 2: Olumsuz Tutum; Faktör 3: Çalışma } \\
\text { Koşulları) }\end{array}$} \\
\hline Sinif & $\begin{array}{l}\text { Faktör } 1 \text { ve Faktör } 3 \text { ile aralarında } \\
\text { istatistiki olarak anlamlı bir farklılık } \\
\text { bulunamamıştır. }\end{array}$ & $\begin{array}{l}\text { Faktör } 2 \text { ile arasında istatistiki olarak } \\
\text { anlamlı bir farklılık bulunmuştur } \\
(\mathrm{p}=0.000<0.05) .\end{array}$ \\
\hline Ailenin Gelir Düzeyi & \multicolumn{2}{|c|}{$\begin{array}{l}\text { Faktör 1, Faktör } 2 \text { ve Faktör } 3 \text { ile aralarında istatistiki olarak anlamlı bir } \\
\text { farklılık bulunamamıştır. }\end{array}$} \\
\hline Anne ve Baba Eğitim Düzeyi & \multicolumn{2}{|c|}{$\begin{array}{l}\text { Faktör 1, Faktör } 2 \text { ve Faktör } 3 \text { ile aralarında istatistiki olarak anlamlı bir } \\
\text { farklılık bulunamamıştır. }\end{array}$} \\
\hline $\begin{array}{l}\text { Anne ve Babanın Pandemi } \\
\text { Sürecindeki Çalışma Durumu }\end{array}$ & \multicolumn{2}{|c|}{$\begin{array}{l}\text { Faktör 1, Faktör } 2 \text { ve Faktör } 3 \text { ile aralarında istatistiki olarak anlamlı bir } \\
\text { farklılık bulunamamıştır. }\end{array}$} \\
\hline Turizm Lisesini Seçme Nedeni & \multicolumn{2}{|c|}{$\begin{array}{l}\text { Faktör 1, Faktör } 2 \text { ve Faktör } 3 \text { ile aralarında istatistiki olarak anlamlı bir } \\
\text { farklılık bulunamamıştır. }\end{array}$} \\
\hline $\begin{array}{l}\text { Üniversitede Tercih Edilmesi } \\
\text { Planlanan Turizm Programı }\end{array}$ & $\begin{array}{l}\text { Faktör } 2 \text { ve Faktör } 3 \text { ile aralarında } \\
\text { istatistiki olarak anlamlı bir farklılık } \\
\text { bulunamamıştır }\end{array}$ & $\begin{array}{l}\text { Faktör } 1 \text { ile arasında istatistiki olarak } \\
\text { anlamlı bir farklıllk bulunmuştur } \\
(\mathrm{p}=0.009<0.05) \text {. }\end{array}$ \\
\hline
\end{tabular}


Faktör analizi sonucunda belirlenen faktörlere ek olarak, öğrencilerin gelecek kaygıları ve ilgili değişkenler arasında Çok Değişkenli Varyans Analizi (MANOVA) uygulanmış ve Tablo 8'de özet bir şekilde verilmiştir. Öğrencilerin sınıfları ile gelecek kaygıları arasında anlamlı bir farklılık bulunmaktadır (Pillai's Trace (sig.) $=0.000 ; p=0.000<0.05$ ). 9. Sinıfların kaygı düzeylerinin 10 . Sınıflara göre anlamlı ve daha yüksek olduğu; fakat 9. Sınıfların kaygı düzeylerinin 11. ve 12. Sınıflara göre anlamlı ve daha düşük olduğu görülmüştür. En yüksek kaygı farkı ise 9. ve 11. Sınıflar arasındadır. Benzer şekilde, ailenin gelir düzeyi ile gelecek kaygıları arasında istatistiki olarak anlamlı bir farklılık tespit edilmiştir. (Pillai's Trace (sig.) $=0.000 ; p=0.040<0.05$ ). Buna göre ailesinin geliri giderinden az olan öğrencilerin geleceğe yönelik kaygı düzeyi, geliri giderinden çok olanlarınkinden daha fazladır. Ayrıca, öğrencilerin liseyi seçme nedenleri ile gelecek kaygıları arasında istatistiki olarak anlamlı bir farklılık bulunmuştur (Pillai's Trace (sig.) $=0.000$; $\mathrm{p}=0.000<0.05$ ). Buna göre, liseyi kendi isteği ile tercih eden öğrencilerin kaygı düzeyi, puanına göre ve başka seçeneği olmadığını düşündüğü için seçenlere göre daha düşüktür. Bunlara karşın, anne ve babanın eğitim düzeyi, anne ve babanın pandemi sürecindeki çalışma durumu ve üniversitede tercih edilmesi planlanan turizm programı değişkenleri ile öğrencilerin gelecek kaygıları arasında anlamlı bir farklılık bulunmamıştır.

Tablo 8. Gelecek Kaygılarına İlişkin Çok Değişkenli Varyans Analizi (MANOVA) Sonuçları

\begin{tabular}{|c|c|}
\hline Değişkenler & $\begin{array}{l}\text { MANOVA Sonuçları } \\
\text { (Gelecek Kaygıları) }\end{array}$ \\
\hline Sinif & $\begin{array}{l}\text { Gelecek kaygıları ile arasında istatistiki olarak anlamlı bir farklılık } \\
\text { bulunmuștur }(p=0.000<0.05) \text {. }\end{array}$ \\
\hline Ailenin Gelir Düzeyi & $\begin{array}{l}\text { Gelecek kaygıları ile arasında istatistiki olarak anlamlı bir farklılık } \\
\text { bulunmuștur }(p=0.040<0.05) \text {. }\end{array}$ \\
\hline Anne ve Baba Eğitim Düzeyi & $\begin{array}{l}\text { Gelecek kaygıları ile aralarında istatistiki olarak anlamlı bir farklılık } \\
\text { bulunamamıştır. }\end{array}$ \\
\hline $\begin{array}{l}\text { Anne ve Babanın Pandemi } \\
\text { Sürecindeki Çalışma Durumu }\end{array}$ & $\begin{array}{l}\text { Gelecek kaygıları ile aralarında istatistiki olarak anlamlı bir farklılık } \\
\text { bulunamamıştır. }\end{array}$ \\
\hline Turizm Lisesini Seçme Nedeni & $\begin{array}{l}\text { Gelecek kaygıları ile arasında istatistiki olarak anlamlı bir farklılık } \\
\text { bulunmuştur }(p=0.000<0.05) .\end{array}$ \\
\hline $\begin{array}{l}\text { Üniversitede Tercih Edilmesi } \\
\text { Planlanan Turizm Programı }\end{array}$ & $\begin{array}{l}\text { Gelecek kaygıları ile aralarında istatistiki olarak anlamlı bir farklılık } \\
\text { bulunamamıştır. }\end{array}$ \\
\hline
\end{tabular}

Faktörlerin birbiri arasındaki ve öğrencilerin gelecek kaygısı konusundaki ilişkisi Korelasyon Analizi aracılığıyla incelenmiştir. Korelasyon analizi, belirli değişkenler arasındaki ilişkinin derecesini, yönünü ve önemini ortaya koymayı sağlayan istatistiki bir yöntemdir (Çolak, 2012). Korelasyon katsayısı, ilişkinin yönünü ve derecesini belirtmekte, açıklanan varyansın açıklanamayan varyansa oranı olarak da açılanmaktadır (Öztürk, 2020). Analize göre, turizm sektörüne yönelik olumlu tutum (faktör 1) ile turizm sektörüne yönelik olumsuz tutum (faktör 2) arasında 0.05 düzeyinde negatif yönlü anlamlı bir ilişki vardır (pearson korelasyon katsayısı= $-0.120^{*}$ ). Beklenen şekilde, turizm sektörüne yönelik olumlu tutum artıkça olumsuz tutum azalmaktadır. Buna ek olarak, faktör 1 (olumlu tutum) ile turizm sektörünün çalışma koşulları (faktör 3) (pearson korelasyon katsayısı $=-0.323^{* *}$ ) ve öğrencilerin geleceğe yönelik plan ve kaygıları (pearson korelasyon katsayısı $=-0.309^{* *}$ ) ile arasında 0.01 düzeyinde negatif yönlü anlamlı bir ilişki bulunmaktadır. Buna göre, turizm sektörüne ilişkin olumlu tutum artıkça hem turizm sektörünün çalışma koşullarına ilişkin olumsuz algı hem de geleceğe yönelik kaygılar azalmaktadır. Turizm sektörüne yönelik olumsuz tutum (faktör 2) ile turizm sektörünün çalışma koşulları (faktör 3) arasında 0.01 düzeyinde pozitif yönlü anlamlı bir ilişki bulunurken (pearson korelasyon katsayısı $=0.353^{* *}$ ); öğrencilerin geleceğe yönelik plan ve kaygıları (pearson 
korelasyon katsayısı $=0.390^{* *}$ ) ile arasında 0.01 düzeyinde negatif yönlü anlamlı bir ilişki bulunmaktadır. Başka bir deyişle, turizm sektörünün çalışma koşullarına ilişkin olumsuz algı artıkça sektöre yönelik olumsuz tutum da artmakta; sektöre yönelik olumsuz tutumun artması ise öğrencilerin gelecek planlarını olumsuz etkilemektedir. Buradan hareketle, en yüksek ilişkinin turizm sektörünün çalışma koşullarına yönelik tutum ile öğrencilerin geleceğe yönelik plan ve kaygıları arasında olduğunu söylemek mümkündür.

\section{SONUÇ ve ÖNERILER}

COVID-19 salgınından kaynaklı küresel kriz, dünyadaki hükümetler ve endüstriler üzerinde ani ve benzeri görülmemiş baskılar oluştururken neredeyse tüm sektörleri etkilemeye devam etmektedir. 2020 yılında tüm dünyayı etkisi altına alan COVID-19 salgını, turizm işletmelerini ve dolayısıyla çalışanlarının geçim kaynaklarını ciddi ölçüde etkilemiş, yüz milyonlarca insanın işsiz kalmasına neden olmuştur. Bu nedenle turizm, pandemiye karşı en savunmasız sektörlerden biri olarak tanımlanmıştır. Öte yandan birçok ülkede devam eden yasaklamalar, hem işyerlerinde hem de sınıfta öğrenmeyi kesintiye uğratmış, mesleki eğitimlerini ve becerileri değerlendirmek ve sonuç olarak yeterlilikleri vermek için kullanılan sistemler de dâhil olmak üzere işyeri tabanlı öğrenim için özellikle yıkıcı olmuştur. Pandeminin hem turizm eğitimine hem de turizm sektörüne verdiği yıkıcı etki nedeniyle çalışmada turizm eğitimi alan lise öğrencilerinin gelecek beklentileri ve turizm sektörüne yönelik algılarının incelenmesi amaçlanmıştır. Araştırma sonuçlarına göre; Hatay ilinde turizm eğitimi gören lise öğrencilerinin (\%57'si erkek, $\% 43$ '̈ kadın), \%67'si turizm alanını kendi isteğiyle tercih etmiştir. \%88,6'sı liseden sonra yükseköğrenime devam etmeyi istemektedir. Öğrenimlerine turizm alanında devam etmek isteyen öğrenci yüzdesi \%70,5'tir. Turizm alanını tercih etmek isteyen öğrencilerin \%64,4'ü gastronomi ve mutfak sanatları, \%18,4'ü turizm işletmeciliği, \%15,5'i seyahat işletmeciliği ve turizm rehberliği ve \%1,7'si rekreasyon yönetimi programlarına yönelmeyi düşünmektedir.

Pandemiye rağmen kariyeri ile ilgili geleceğe umutla bakan ve turizm sektöründe çalışmaya devam etmek isteyen öğrencilerin oranı yüksektir. Fakat bu süreçte lise mezuniyeti sonrası iş bulma umut ve inançlarının olmadığı görülmektedir. Aldıkları eğitimin yeterli olduğunu bu şekilde sektörde başarılı olabileceğine inanan öğrenci sayısı yüksektir. Ancak yine de öğrenciler (\%71,5'i) bir üst eğitime (üniversiteye) devam etmek istediklerini, böylece kısa sürede iyi noktalara gelineceğine inandıklarını bildirmiştir. Öte yandan, pandemi sebebiyle turizm sektörünün güvenilir bir seçim olmadığını düşünenlerin oranı $\% 44,7^{\prime}$ dir. Geleceğe yönelik kayg1 durumunda, üniversite okuma düşüncesi olmayanların veya turizmden farklı bir alanda yükseköğrenimlerine devam etmeyi düşünenlerin gelecek kaygısının daha yüksek olduğu, kız öğrencilerin erkeklere nazaran daha kaygılı, 9. sınıfların gelecek kaygılarının diğer sınıflara göre daha yüksek olduğu bulgulanmıştır. Ayrıca ailesinin geliri giderinden az olan öğrencilerin geleceğe yönelik kaygı düzeylerinin, geliri giderinden çok olanlarınkinden daha fazla olduğu, turizmi kendi isteği ile tercih eden öğrencilerin, başka nedenlerle tercih edenlere göre kaygı düzeylerinin daha düşük olduğu sonucuna ulaşılmıştır. Sonuç olarak uzun vadede öğrencilerin büyük çoğunluğunun kariyer gelişimlerinde geleceğe umutla baktıkları ve bu durumu yüksek öğrenimlerine devam ederek perçinlemek istedikleri görülmektedir.

Turizm eğitimi alan lise öğrencilerinin turizm sektörüne yönelik tutumlarına ilişkin ifadelere verdikleri yanıtlardan yola çıarak, turizm sektörünün sosyalleşme aracı olarak görüldüğü söylenebilir. Bu sonuçlar Türker, Uçar ve Ateş (2016), Dagsland, Mykletun ve Einarsen (2017), ile Kocaman ve Koybu Rol'ün (2020) araştırma bulgularıyla örtüşmektedir. Diğer bir yandan çalışma koşullarının ağır olduğu, iş güvenliği risklerinin bulunduğu, mevsimsel bir özelliğe sahip oluşu nedeniyle sektörün güven vermediği görüşü öğrenciler arasında yaygın 
görülmüştür. Kız öğrenciler erkek öğrencilere göre turizm sektörü çalışma koşullarının daha ağır olduğunu düşünmektedir. Konaklama ve seyahat hizmetleri alanındaki lise öğrencileri, yiyecek ve içecek hizmetleri alanındakilere nazaran turizm sektörüne ilişkin daha olumsuz bir tutuma sahiptirler. Beklenilenin dışında bir sonuç ise turizm alanında eğitimlerine devam etmeyi düşünenlerin turizm sektörüne yönelik olumsuz tutumlarının da daha yüksek çıkmasıdır. Buradan hareketle, turizm alanında eğitimlerine devam etmek isteyen turizm lisesi öğrencilerinin turizm sektörünün hem olumsuz hem de olumlu yanlarını görerek, bilinçli bir şekilde tercih yapacağı çıarımını yapmak mümkündür. Son sınıf öğrencileri 9,10 ve 11 . sınıf öğrencilerine göre turizm sektörüne karşı daha fazla olumsuz tutum içerisindedir. Bunun sebebi ise öğrencilerin lise son sınıfa geldiklerinde, yaptıkları staj aracılığıyla sektörün "gerçek yüzünü" görmüş olmaları, üniversiteye geçiş sürecinin stresi ve gelecek endişelerindeki artış ile açılanabilmektedir. Gastronomi ve mutfak sanatları veya seyahat işletmeciliği ve turizm rehberliği programlarını tercih etmeyi düşünen öğrenciler, turizm işletmeciliğini tercih etmeyi düşünenlere göre, turizm sektörüne yönelik daha olumlu bir tutum sergilemektedir. Bu durumun, turizm işletmeciliği öğrencilerinin iş tanımlarının gastronomi ve mutfak sanatları veya seyahat işletmeciliği ve turizm rehberliği mezunlarınınki kadar net olmamasından kaynaklandığ düşünülmektedir. Öyle ki, gastronomi ve mutfak sanatları mezunlarının sektörde mutfak departmanında istihdam edileceği; benzer bir şekilde, seyahat işletmeciliği ve turizm rehberliği mezunlarının dil puanını sağlamaları halinde "kokartlı turist rehberi" olabileceği yadsınamaz bir gerçektir. Buna karşın, turizm işletmeciliği mezunlarının kesin bir iş tanımı yapılamamaktadır. Örneğin, halen otel çalışanlarına ilişkin bir meslek yasası bulunmamaktadır. Bu durum öğrencilerin gelecek beklentilerini ve turizme ilişkin algılarını etkilemektedir. Genel olarak ise öğrencilerin turizm sektörüne karşı olumsuz tutumlarının çalışma koşullarından kaynaklandığ 1 görülmektedir. Ortaya çıkan bu sonuç; Kusluvan ve Kusluvan (2000), Unur, ve Köşker (2015) Üzümcü, Alyakut ve Günsel (2015), Türker, Uçar ve Ateş (2016), Tuna, Akça, Akbaş Tuna ve Gürlek (2017), Akyol, Oğan ve Oğan (2018), Kocaman ve Koybu Rol'ün (2020) araştırma bulgularıyla benzerlik göstermektedir.

Araştırmaya Yönelik Öneriler: Mevcut araştırmanın sonuçları; öğrencilerin \%64,4'ü gastronomi ve mutfak sanatları, \%18,4'ü turizm işletmeciliği, \%15,5'i seyahat işletmeciliği ve turizm rehberliği ve \%1,8'i rekreasyon yönetimi programlarına yönelmeyi düşündüklerini göstermektedir. Turizm, güzel sanatlar vb. fakülteler ile turizm ve uygulamalı bilimler yüksekokulları bünyesinde yer alan gastronomi ve mutfak sanatları bölümünün popülerliği son yıllarda git gide artmaktadır. Mevcut araştırmanın sonuçları da bu duruma işaret etmektedir. Fakat öte yandan diğer programlara yönelme fikri oranının düşük olduğu tespit edilmiştir. Bu sonuçların altında yatan nedenlerin kapsamlı bir şekilde ele alınması önerilmektedir. Bu noktada, iş tanımlarının netliğinin ve meslek yasasının olup olmayışının öğrencilerin program tercihlerine nasıl etki ettiği araştırılmalı; etkili olduğu görülmesi durumunda turizm fakültesindeki programlardan mezun olanların iş tanımlarına ilişkin arama konferansları veya çalıştaylar düzenlenmelidir. Ayrıca turizm alanında eğitim gören lise öğrencilerine, ilgili fakülte ve yüksekokulların bu bölümler hakkında tanıtım etkinlikleri düzenlemeleri de bir diğer öneridir. Benzer şekilde, büyük bir kısmı $(\% 70,5)$ turizm alanında eğitimlerine devam etmeyi düşünen lise öğrencileri ile sektörün iş birliği kuvvetlendirilmelidir. Öğrenciler turizm sektörünü, sektörün içinden kişilerden de dinlemeli, turizmin farklı alanlarındaki ve departmanlarındaki yetkililerden bakış açısı kazanmalıdır. Öğrencilerin, üniversite alanlarını salt "popülerite" odaklı seçmesindense bilgi, beceri ve yeteneklerine göre seçmesi önemlidir. Bu noktada, lise ve sektör iş birliği içerisinde davranarak öğrencilerin kariyer yollarını çizmelerinde yardımcı olmalıdır. Daha bilinçli ve istekli bir şekilde geleceklerini tasarlayan öğrencilerin, gelecek kaygılarının daha az olacağı ve turizm sektörüne yönelik algılarının daha yüksek olacağı düşünülmektedir. 
Turizm sektörünün çalışma koşulları, öğrencilerin sektöre ilişkin olumsuz tutumunu etkileyen en önemli faktörlerden biridir. Turizm sektörü, yapısı gereği, $7 / 24$ işler bir halde olduğu için çalışma saatlerinin fazla olması kaçınılmaz bir durumdur. Buna karşın, sektördeki çalışma koşullarının iyileştirilmesi, sektöre yönelik tutumları düzeltebilecek ve çalışanları daha motive hale getirebilecektir.

Mevcut çalışma Hatay ilinde gerçekleşmiştir. Hatay'ın bir "gastronomi şehri" olmasının çalışmanın çeşitli noktalarını (özellikle üniversitede tercih edilecek bölüm faktörünü) etkileyebileceği düşünülmektedir. Bu nedenle benzer çalışmanın turizm şehri olarak nitelendirilebilecek farklı şehirlerde tekrarlanması önerilmektedir. Son olarak, bu çalışma lise öğrencilerinin katılımlarıyla gerçekleştirilmiştir. Dolayısıyla gelecekteki çalışmalar üniversite öğrencileri ile gerçekleştirilebilir ve lise öğrencileri ile kıyaslamalı bir çalışma yürütülebilir.

\section{KAYNAKLAR}

Airey, D., and Frontistis, A. (1997). Attitudes to Careers in Tourism: An Anglo Greek Comparison. Tourism Management, 18(3), 149-158.

Akpulat, N. A. (2020). Turizm Öğrencilerinin İş Güvencesizliği ve Kariyer İyimserliğinin Turizm Sektörü Algısını Etkilemesi Üzerine Bir Araştırma. Celal Bayar Üniversitesi Sosyal Bilimler Dergisi, 18(01), 170-190.

Akyol, C., Oğan, E., ve Oğan, Y. (2018). Turizm Eğitimi Alan Üniversite Öğrencilerinin Mesleki Beklentileri ve Sosyo-Ekonomik Profilleri Üzerine Bir Araştırma. Gaziantep University Journal of Social Sciences, 17(2), 648-665.

Alaeddinoğlu, F., ve Rol, S. (2020). Covid-19 Pandemisi ve Turizm Üzerindeki Etkileri. Van Yüzüncü Yıl Üniversitesi Sosyal Bilimler Enstitüsü Dergisi, Salgın Hastalıklar Özel Sayısı, 233-258.

Aytaç, K. (2006). Çă̆daş Ĕ̆itim Akımları (Yabancı ülkelerde). Ankara: Mevsimsiz Yayınları.

Bartlett, M. S. (1950). Tests of Significance in Factor Analysis. British Journal of Statistical Psychology, 3(2), 77-85.

Bolat, Y. (2016). Türkiye'de Meslekî ve Teknik Eğitimin Mevcut Durumu ve Farklı Ülkelerle Karşılaştırılması. Ankara: Pegem Akademi Yayınları.

Coşkun, R., Altunışık, R., Bayraktaroğlu, S., ve Yıldırım, E. (2015). Sosyal Bilimlerde Araştırma Yöntemleri. Sakarya: Sakarya Yayıncilık.

Çatı, K., ve Bilgin, Y. (2013). Turizm Lisans Öğrencilerinin Turizm Sektöründe Çalışma Eğilimleri. CÜ İktisadi ve İdari Bilimler Dergisi, 14(1), 23-46.

Çavuş, Ş., ve Kaya, A. (2015). Turizm Lisans Eğitimi Alan Öğrencilerin Kariyer Planları ve Turizm Sektörüne Yönelik Tutumu. Manas Sosyal Araştırmalar Dergisi, 4(5), 101-117.

Çokluk ,Ö., Şekercioğlu, G., ve Büyüköztürk, Ş. (2012). Sosyal Bilimler İ̧̧in Çok Değişkenli İstatistik SPSS ve Lisrel Uygulamaları. Ankara: Pegem Akademi Yayınları.

Çolat, E. (2012). Korelasyon Analizi (Powerpoint Sunumu). Eskişehir Osmangazi Üniversitesi Tıp Fakültesi Biyoistatistik Anabilim Dalı. https://eczacilik.anadolu.edu.tr/bolumSayfalari/belgeler/ecz2014\%2012_20140527094539.pdf.

(Erişim Tarihi: 01.07.2021). 
Dagsland, Å. H. B., Mykletun, R. J., and Einarsen, S. (2017). Antecedents of Norwegian Adolescents' Choice of Educational Pathway in Hospitality and Tourism. Nordic Journal of Working Life Studies, 7(4), 51-71.

Davras, G. M., ve Alili, M. (2019). Turizm Eğitimi Alan Üniversite Öğrencilerinin Gelecek Beklentileri Üzerine Bir Araştırma. Uluslararası Global Turizm Araştırmaları Dergisi, 3(1), 40-52.

Duman, T., Tepeci, M., ve Unur, K. (2006). Mersin'de Yükseköğretim ve Orta Öğretim Düzeyinde Turizm Eğitimi Almakta Olan Öğrencilerin Sektörün Çalışma Koşullarını Algılamaları ve Sektörde Çalışma İsteklerinin Karşılaştırmalı Analizi. Anatolia: Turizm Araştırmaları Dergisi, 17(1), 51-69.

Field, A. (2000). Discovering Statistics Using SPSS for Windows: Advanced Techniques for the Beginner. Sage Publications. London.

George, D., and Mallery, M. (2010). SPSS for Windows Step by Step: A Simple Guide and Reference, 17.0 Update (10th ed.) Boston: Pearson.

Goodger, D. and Ferran, K. (2020). City Tourism Outlook and Ranking: Coronavirus Impacts and Recovery. Tourism Economics https://resources.oxfordeconomics.com/hubfs/City-TourismOutlook-and-Ranking.pdf (Erişim Tarihi: 10.03.2021).

Halıc1, A., ve Delil, Y. (2003). Büro Yönetimi Öğrencilerinin Mesleki Algılamalarının Belirlenmesine Yönelik Bir Uygulama. Gazi Üniversitesi Ticaret ve Turizm Eğitim Fakültesi Dergisi, (1), 22-37.

ILO (2020). Sectoral Brief, COVID-19 and the Tourism Sector. https://www.ilo.org/sector/Resources/publications/WCMS_741468/lang--en/index.htm (Erişim Tarihi: 12.03.2021).

Jenkins, A. K. (2001). Making a Career of it? Hospitality Students' Future Perspectives: An AngloDutch Study. International Journal of Contemporary Hospitality Management, 13(1), 13-20.

Kalkınma Bakanlığı (2014). 2014-2018 Kalkınma Planı. Mesleki Eğitimin Yeniden Yapılandırılması Çalışma Grubu Raporu. Ankara: Kalkınma Bakanlığı. ISBN 978-605-4667-98-7.

Kocaman, S., ve Koybu Rol, E. P. (2020). Öğrencilerin Mesleki Alg1 ve Beklentileri İle Gelecek Kaygılarının Sektörde Çalışma İsteği Üzerine Etkisi: Antalya Yükseköğretim Turizm Öğrencilerine Yönelik Bir Araştırma. Journal of Tourism and Gastronomy Studies, 8(4), 3192-3217.

Köşker, H., ve Unur, K. (2017). Turizm Lisans Öğrencilerinin Turizm Sektöründe Çalışma Eğilimleri Üzerine Bir Araştırma. Seyahat ve Otel İşletmeciliği Dergisi, 14(2), 126-141.

Kusluvan, S., and Kusluvan, Z. (2000). Perceptions and Attitudes of Undergraduate Tourism Students Towards Working in the Tourism Industry in Turkey. Tourism Management, 21(3), 251269.

Lee, C. C., and Chen, C. J. (2011). The Reaction of Elderly Asian Tourists to Avian Influenza and SARS. Tourism Management, 32(6), 1421-1422

Millî Eğitim Bakanlı̆̆1 (2018c). Türkiye'de Mesleki ve Teknik Eğitimin Görünümü http://mtegm.meb.gov.tr/meb_iys_dosyalar/2018_11/12134429_No1_Turkiyede_Mesleki_ve_Te knik_Egitimin_Gorunumu.pdf (Erişim Tarihi: 10.04.2021).

Millı̂ Eğitim Bakanlığı (2020a). Millî Eğitim İstatistikleri Örgün Eğitim 2019-2020 https://sgb.meb.gov.tr/meb_iys_dosyalar/2020_09/04144812_meb_istatistikleri_orgun_egitim_20 19_2020.pdf (Erişim Tarihi: 10.04.2021). 
Millî Eğitim Bakanlığı (2020b). Covid-19 Salgını Sürecinde Mesleki ve Teknik Eğitim. https://mtegm.meb.gov.tr/meb_iys_dosyalar/2020_11/27153729_turkiye_raporu_turkce_23.10.20 20_1.pdf (Erişim Tarihi: 12.03.2021).

OECD (2020a). Policy Responses to Coronavirus (COVID-19; Tourism Policy Responses to the Coronavirus (COVID-19). https://www.oecd.org/coronavirus/policy-responses/tourism-policyresponses-to-the-coronavirus-covid-19-6466aa20/ (Erişim Tarihi: 12.03.2021).

OECD (2020b). OECD Policy Responses to Coronavirus (COVID-19) VET in a Time of Crisis: Building Foundations for Resilient Vocational Education and Training Systems. https://read.oecd-ilibrary.org/view/?ref=132_132718-fdwmrqsgmy\&title=VET-in-a-time-ofcrisis-Building-foundations-for-resilient-vocational-education-and-training-systems- (Erişim Tarihi: 18.03.2021).

Olcay, A., ve Çelik, Z. (2010). Turizm ve Otel İşletmeciliği Programında Öğrenim Gören Öğrencilerin Otelcilik Mesleğine İlişkin Algıları. Gaziantep University Journal of Social Sciences, 9(2), 279 -301.

Öztürk, E. E. (2020). Korelasyon Analizi Nedir? Veri Bilimi Okulu. https://www.veribilimiokulu.com/korelasyon-analizir-nedir/. (Erişim Tarihi: 01.07.2021).

Ross, G. F. (1994). What do Australian School Leavers Want of the Industry? Tourism Management, 15(1), 62-66.

Tabachnick, B. G., Fidell, L. S., and Ullman, J. B. (2007). Using Multivariate Statistics (Vol. 5, Pp. 481-498). Boston, MA: Pearson.

Tuna, M., Akça, İ., Akbaş Tuna A., ve Gürlek, M. (2017). Turizm Öğrenimi Gören Öğrencilerin Sektör Çalışma Koşullarını Algılamaları ve Sektörde Çalışmaya Yönelik Tutumları: Meslek Yüksekokulu, Yüksekokul ve Fakülte Öğrencilerine Yönelik Bir Araştırma. Turizm Akademik Dergisi, 4(2), 41-60.

Türker, N., Uçar, M., ve Ateş, M. A. (2016). Turizm Eğitimi Alan Öğrencilerin Turizm Sektörü Algıları: Karabük Üniversitesi Öğrencileri Üzerine Bir Araştırma. Karabük Üniversitesi Sosyal Bilimler Enstitüsü Dergisi, 6(2), 311-333.

UNTWO (2021a). 2020: Worst Year in Tourism History with 1 Billion Fewer International Arrivals. https://www.unwto.org/news/2020-worst-year-in-tourism-history-with-1-billionfewer-international-arrivals (Erişim Tarihi: 12.03.2021).

Unur, K., ve Köşker, H. (2015). Türkiye'de Turizm Eğitimi ve Turizm Eğitimi Alan Öğrencilerin Turizme Bakış Açılarına Yönelik Araştırmaların İncelenmesi. Că̆ University Journal of Social Sciences, 12(1), 44-71.

UNWTO (2020b). UNWTO World Tourism Barometer May 2020 - Special Focus on the Impact of COVID-19. $\quad$ https://webunwto.s3.eu-west-1.amazonaws.com/s3fs-public/202005/BAROM_UNWTO_Webinar.pdf (Erişim Tarihi: 12.03.2021).

Uzunsakal, E., ve Yıldız, D. (2018). Alan Araştırmalarında Güvenilirlik Testlerinin Karşılaştırılması ve Tarımsal Veriler Üzerine Bir Uygulama. Uygulamalı Sosyal Bilimler Dergisi, 2(1), 14-28.

Üzümcü, T. P., Alyakut, Ö., ve Günsel, A. (2015). Turizm Eğitimi Alan Öğrencilerin, Mesleğin Geleceğine İlişkin Bakış Açıları. Balıkesir Üniversitesi Sosyal Bilimler Enstitüsü Dergisi, 18(33), 179199. 
World Bank (2020). The COVID-19 Pandemic: Shocks to Education and Policy Responses, World Bank, Washington, DC. https://policycommons.net/artifacts/1278910/the-covid-19-pandemic/ on 18 Mar 2021. CID: 20.500.12592/jx79wv (Erişim Tarihi: 18.03.2021).

Yazıcıoğlu, Y., ve Erdoğan, S. (2004). SPPS Uygulamalı Bilimsel Araştırma Yöntemleri. Ankara: Detay Yayıncilık. 